\title{
SLUDGE BATCH 3 MELT RATE ASSESSMENT
}

\section{T.H. Lorier \\ D.K. Peeler \\ D.C. Koopman \\ T.B. Edwards}

Westinghouse Savannah River Company

Savannah River Technology Center

Aiken, South Carolina

Westinghouse Savannah River Company

Savannah River Technology Center

Aiken, SC 29808

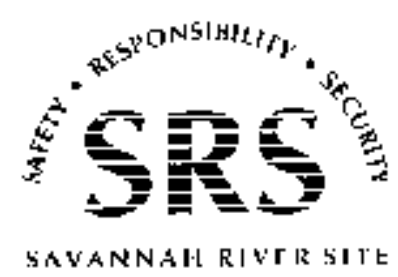

PREPARED FOR THE U.S. DEPARTMENT OF ENERGY UNDER CONTRACT NO. DE-AC09-96SR18500 
This document was prepared in conjunction with work accomplished under Contract No. DE-AC09-96SR18500 with the U. S. Department of Energy.

\section{DISCLAIMER}

This report was prepared as an account of work sponsored by an agency of the United States Government. Neither the United States Government nor any agency thereof, nor any of their employees, makes any warranty, express or implied, or assumes any legal liability or responsibility for the accuracy, completeness, or usefulness of any information, apparatus, product or process disclosed, or represents that its use would not infringe privately owned rights. Reference herein to any specific commercial product, process or service by trade name, trademark, manufacturer, or otherwise does not necessarily constitute or imply its endorsement, recommendation, or favoring by the United States Government or any agency thereof. The views and opinions of authors expressed herein do not necessarily state or reflect those of the United States Government or any agency thereof.

This report has been reproduced directly from the best available copy.

Available for sale to the public, in paper, from: U.S. Department of Commerce, National Technical Information Service, 5285 Port Royal Road, Springfield, VA 22161, phone: (800) 553-6847, fax: (703) 605-6900

email: orders@ntis.fedworld.gov

online ordering: http://www.ntis.gov/help/index.asp

Available electronically at http://www.osti.gov/bridge

Available for a processing fee to U.S. Department of Energy and its contractors, in paper, from: U.S. Department of Energy, Office of Scientific and Technical Information, P.O. Box 62, Oak Ridge, TN 37831-0062,

phone: (865)576-8401,

fax: (865)576-5728

email: $\underline{\text { reports@ adonis.osti.gov }}$ 
Immobilization Technology Section

WSRC-TR-2003-00027

Savannah River Technology Center

Rev. 0

Westinghouse Savannah River Company

\title{
SLUDGE BATCH 3 MELT RATE ASSESSMENT
}

\author{
T.H. Lorier \\ D.K. Peeler \\ D.C. Koopman \\ T.B. Edwards
}

Westinghouse Savannah River Company

Savannah River Technology Center

Aiken, South Carolina

This report was prepared by Westinghouse Savannah River Company (WSRC) for the United States Department of Energy under Contract No. DE-AC09-96SR18500 and is an account of work performed under that contract. 
Immobilization Technology Section

WSRC-TR-2003-00027

Savannah River Technology Center

Rev. 0

Westinghouse Savannah River Company

This page intentionally left blank. 


\section{Executive Summary}

Results of the melt rate study conducted in support of the development of a Sludge batch 3 (SB3) flowsheet are presented in this report. These results are an important part of the overall strategy for frit development and optimization for this sludge batch and contribute, along with the supporting paper studies and glass variability studies, to the information that will be evaluated to select a frit for a targeted SB3 decant. These results also contribute to the demonstration of the viability of this overall strategy as a reliable approach for frit development and optimization for future sludge batches.

Two SB3 compositional views (Decant \#5 and Decant \#9), representing an interval of washing endpoints, were used to represent this sludge. The frits selected for these experimental activities were identified by paper studies as providing attractive operating windows for these sludge compositions (based upon model predictions of viscosity and product quality). Efforts were taken to minimize the impact of other processing considerations, such as acid addition and waste loading, on the melt rates of the frit / sludge systems studied. Based on the results of this testing, four primary candidate SB3 frits were identified for both Decant \#5 and Decant \#9. These frits demonstrated relatively high melt rates (as compared to the other frits evaluated in this study) as a function of waste loading which ultimately translated into high waste throughput potentials. 
Immobilization Technology Section

WSRC-TR-2003-00027

Savannah River Technology Center

Rev. 0

Westinghouse Savannah River Company

This page intentionally left blank. 


\section{Acronyms}

\begin{tabular}{|c|c|}
\hline AES & atomic emission spectroscopy \\
\hline DOE & U.S. Department of Ene rgy \\
\hline DWPF & Defense Waste Processing Facility \\
\hline DWPF PE & Defense Waste Processing Facility Process Engineering \\
\hline $\mathrm{EV}$ & extreme vertice \\
\hline HLW & high-level waste \\
\hline HLW CP\&A & High-Level Waste Chemical Processing and Analytical \\
\hline $\mathrm{IC}$ & ion chromatography \\
\hline ICP & inductively coupled plasma \\
\hline MAR & Measurement Acceptability Region \\
\hline MRF & melt rate furnace \\
\hline PCCS & Product Composition Control System \\
\hline SB & sludge batch \\
\hline SMRF & slurry-fed melt rate furnace \\
\hline SRAT & Sludge Receipt and Adjustment Tank \\
\hline SRS & Savannah River Site \\
\hline SRTC & Savannah River Technology Center \\
\hline SRTC-ML & Savannah River Technology Center - Mobile Laboratory \\
\hline $\mathrm{T}_{\mathrm{L}}$ & liquidus temperature \\
\hline $\mathrm{T}_{\mathrm{M}}$ & melt temperature \\
\hline $\mathrm{TIC}$ & total inorganic carbon \\
\hline TTR & technical task request \\
\hline WL & waste loading \\
\hline
\end{tabular}


Immobilization Technology Section

WSRC-TR-2003-00027

Savannah River Technology Center

Rev. 0

Westinghouse Savannah River Company 


\section{Contents}

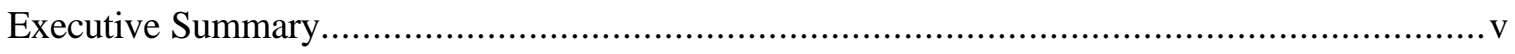

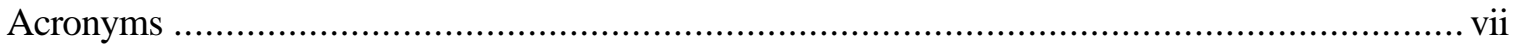

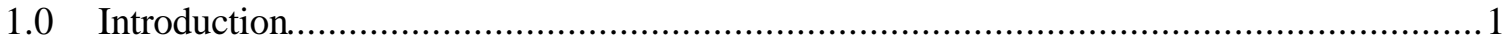

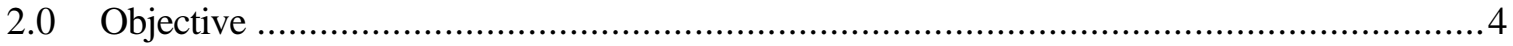

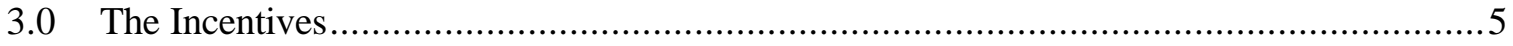

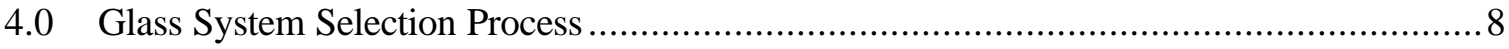

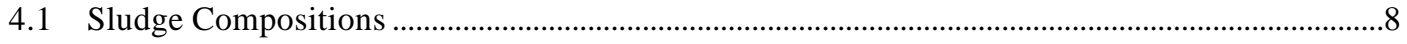

4.2 Frit Selection Process...............................................................................................................

4.2.1 Decant \#5: Phase 2 Assessment ....................................................... 11

4.2.2 Decant \#9: Phase 2 Assessment ................................................................. 12

4.2.3 The Down-Select Process ............................................................. 13

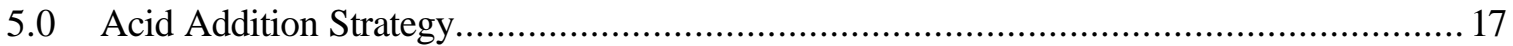

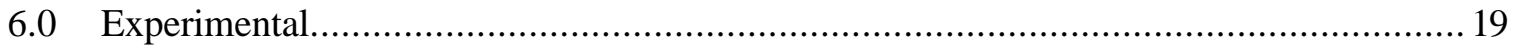

6.1 Preparation of Decant \#5 and Decant \#9 Sludge Simulants ..........................................................19

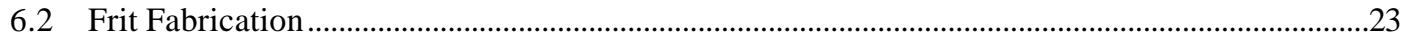

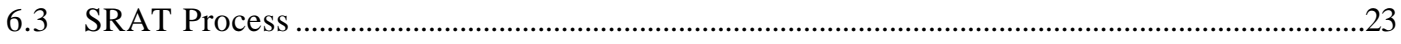

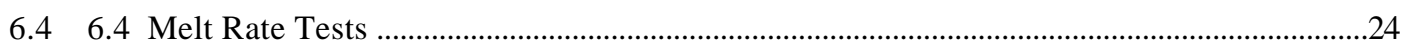

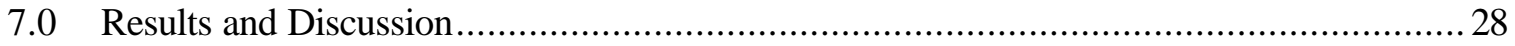

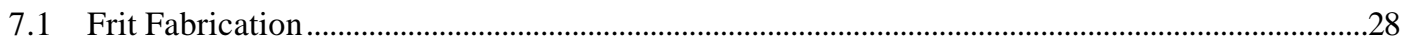

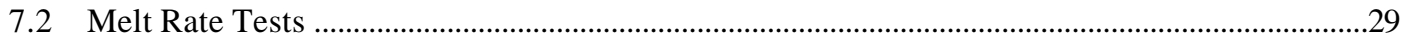

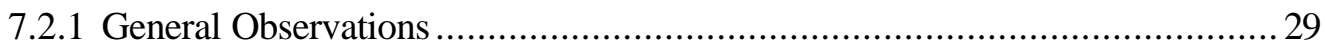

7.2.2 Decant \#5-Based Systems …............................................................... 30

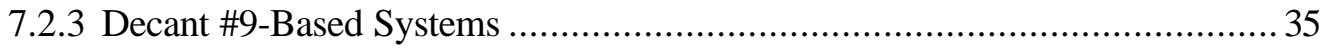

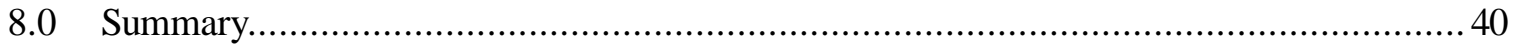

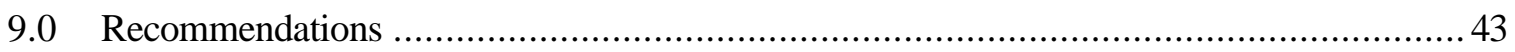

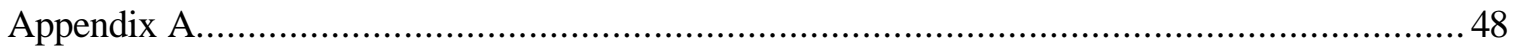


Immobilization Technology Section

WSRC-TR-2003-00027

Savannah River Technology Center

Rev. 0

Westinghouse Savannah River Company

\section{List of Figures}

Figure 3-1. Linear Melt Rates for Frit 320 with SB2 as a Function of Waste Loading ..................................... 6

Figure 3-2. Waste Throughput for Frit 320 with SB2 as a Function of Waste Loading .................................. 7

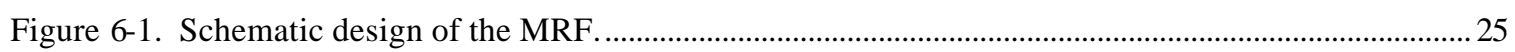

Figure 6-2. Schematic of beaker inserted into the MRF............................................................................... 26 
Immobilization Technology Section

WSRC-TR-2003-00027

Savannah River Technology Center

Rev. 0

Westinghouse Savannah River Company

This page intentionally left blank. 


\section{List of Tables}

Table 4-1. Projected SB3 Compositions of the Radioactive Decant \#5 and Decant \#9 sludges (oxide basis,

$$
\text { wt } \% \text { ). }
$$

Table 4-2. Target Compositions of the Non-Radioactive Decant \#5 and Decant \#9 Sludges (oxide basis, $\mathrm{wt} \%)$

Table 4-3. Nominal Compositions of Candidate Frits (in wt\% on an oxide basis)........................................... 13

Table 4-4. Primary Frit Candidates for Decant \#5 ............................................................................................. 14

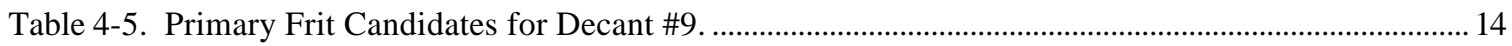

Table 6-1. Compositions (oxide basis, wt\%) of Tested Decants (Pre- and Post-Addition of Trim

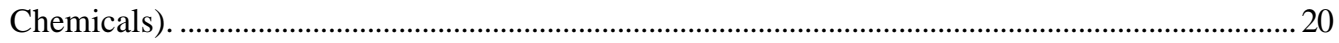

Table 6-2. Sludge Target and Measured Compositions of Decants \#5 and \#9 (oxide basis, wt\%)............... 21

Table 6-3. Anion Target and Measured Compositions of Decants \#5 and \#9................................................... 22

Table 6-4. Additional Characterization Data for Decant \#5 and Decant \#9 Sludges........................................ 22

Table 6-5. Acid Targets for Decant \#5 and Decant \#9 Processing.................................................................... 24

Table 6-6. Frits Tested for SB3 (Decants \#5 and \#9) and Waste Loading Designation.................................... 27

Table 7-1. Target Versus Measured Compositions (wt \%) for SB3 Candidate Frits.......................................... 28

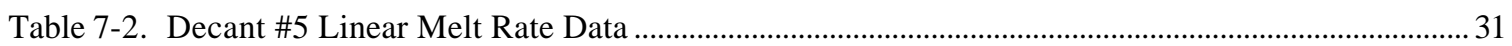

Table 7-3. Linear Melt Rate as a Function of WL for the Frit 320 / SB2 System............................................ 33

Table 7-4. Linear Melt Rates for Various Frit / SB Systems as a Function of WL........................................... 33

Table 7-5. Waste Throughput and Melt Rate Observations for Decant \#5 Candidate Frits............................. 34

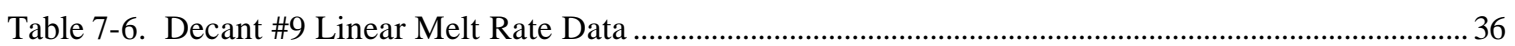

Table 7-7. Waste Throughput and Melt Rate Observations for Decant \#9 Candidate Frits............................ 39

Table 8-1. Summary Information for the Primary Decant \#5 Frits...................................................................... 41

Table 8-2. Summary Information for the Primary Decant \#9 Frits....................................................................... 42 


\subsection{Introduction}

Approximately $130 \mathrm{M}$ L of sludge / supernate high-level radioactive waste (HLW) is currently stored in underground carbon steel tanks at the Savannah River Site (SRS) in Aiken, South Carolina. The Defense Waste Processing Facility (DWPF) began immobilizing these wastes in borosilicate glass in 1996. Currently, the radioactive glass is being produced as a "sludge-only" composition by combining washed high-level sludge with glass frit and melting. The molten glass is poured into stainless steel canisters that will eventually be disposed of in a permanent geological repository.

Currently, the DWPF is processing Sludge Batch 2 (SB2) and is planning to start processing Sludge Batch 3 (SB3) in the spring of 2004 (WSRC 2001). ${ }^{1}$ A sludge batch is defined as a single tank of sludge slurry or a combination of sludge slurries from different tanks that has been or will be qualified for eventual transfer to DWPF. Sludge Batch 3 will be primarily Tank 7 sludge mixed with the heel of Sludge Batch 1B (SB1B), contributions from Tanks 18 and 19, an HCanyon slurry containing precipitated Pu with Gd (Jilani 2002), and an Am/Cm precipitate from F-Canyon (Patel 2002). The sludge from Tank 7 is expected to contain several components that are considered atypical of DWPF sludge to date including higher levels of noble metals than previously processed sludge batches (Peeler et al. 2002a), sand, coal, sodium oxalate, and zeolite (Jantzen et al. 2002). Based on the process history for Tank 7, it is estimated that significant quantities of sand / coal $(\sim 7723 \mathrm{~kg})$ and sodium oxalate $(\sim 300,000 \mathrm{~kg})$ have been added to this tank (Goslen 1984; Fowler 1980).

The quantities of sand, coal, and sodium oxalate may impact several processing parameters at the DWPF. The DWPF has issued a Technical Task Request (TTR) requesting the Savannah River Technology Center (SRTC) to address these processing impacts (Rios-Armstrong 2002a). Fellinger (2002) provided a list of the various tasks that are currently being addressed prior to DWPF's acceptance of SB3. Studies have been and are being performed by SRTC to assess the effects of sand, coal, sodium oxalate, the Pu/Gd stream, and the higher levels of noble metals on various SB3 issues [Herman et al. (2002a); Peeler et al. (2002a); Bronikowski et al. (2002); Jantzen (2002); Herman et al. (2002b); Herman (2002a); Herman (2002b); Herman et al. (2003); and Peeler and Edwards (2002)].

One of the tasks identified by Fellinger (2002) involved an evaluation of potential frits for SB3. Rios-Armstrong (2002b) issued a more specific TTR to address the frit development activity as well as a subsequent variability study.

Peeler and Edwards (2002) indicate that there are several key criteria or aspects that form the integrated methodology for developing and ultimately selecting a frit for SB3. These include:

- Maximizing the Product Composition Control System (PCCS) projected operational window size over the anticipated SB3 composition region,

- Providing a frit that is robust or insensitive to anticipated sludge composition variation,

- Improving or maintaining waste loadings (WLs),

1 Although the current HLW System Plan (WSRC 2001) projects the initiation of SB3 processing in the spring of 2004, plans to expedite processing of SB3 are currently being assessed. If proven feasible, processing of SB3 could begin as soon as the spring/summer of 2003 . 
- Improving or maintaining melt rates,

- Selecting a waste loading and frit that maximizes waste throughput, and

- Providing a "frittable" frit composition. ${ }^{2}$

Given the six key criteria can be competing, the basis for not only developing but ultimately selecting a frit for SB3 is complex. The selection process should not be made based on a single criterion but on a collection of criteria that provide insight into the ease of processing SB3 while still making an acceptable glass. A balanced approach should be utilized in both the development and selection.

The criteria listed above are being used to guide the SB3 frit development task in an effort to establish a baseline flowsheet for SB3 in terms of ease of processing, waste loading, and/or melt rate. $^{3}$ The ability to maximize the size of the DWPF PCCS operational window provides flexibility in targeting waste loadings to meet processing goals. This is strictly an ease-ofprocessing goal targeted to provide as large of a compositional operating window and as much flexibility as possible.

Peeler and Edwards (2002) summarize model-based assessments of existing and newly developed frit compositions for various SB3 washing scenarios (insight into the first three criteria listed above). A unique, but technically sound methodology was developed and implemented for that study to guide frit development activities. The methodology utilized was a sequential, iterative process capable of discerning the effects of frit composition on the projected PCCS operational windows and robustness to sludge variation. Providing a frit that is robust or insensitive to relatively large variations in sludge composition (yields a relatively large processing window when accounting for composition variation) is a major advantage. A "robust" frit will reduce uncertainties or questions associated with how the frit will respond to SB3 once the qualification sample is obtained and compared to what is being used as the nominal or targeted composition in current testing. A viable frit should not only be able to process the nominal SB3 composition being used but should also be able to process (i.e., be robust to) realistic variations of that composition while still maintaining adequate processing and product characteristics. The degree of tolerance can be measured by the ability to produce acceptable glasses as one transitions from the nominal sludge case to compositions representing larger and larger variation about the nominal. Comparisons among the frits were conducted using objective metrics that were developed to aid in this decision making process.

The model-based assessments indicate that judicious selection of the frit can yield processable and durable products at attractive waste loadings for all washing scenarios. The results provided support for the concept of developing specific frits for specific sludges to optimize PCCS operational windows and waste throughput. The results suggested that an aggressive washing strategy may not be required to assure processability or product quality as long as alternative frits are considered (assuming there are no other glass- or process-related restrictions such as anion solubility, $\mathrm{H}_{2}$ generation, redox control, or rheological control issues). Peeler and Edwards (2002) stress that the assessments were based solely on PCCS model predictions which did not include assessments of melt rate or frittability that are part of the integrated testing methodology. The waste loading projections were not influenced by assessments of melt rate or cold cap behavior given there is currently no model to perform such an evaluation that is sensitive enough

\footnotetext{
The term of "frittable" refers to the ability to p roduce a prefabricated frit (glass) from the proposed glass additives. Waste loading (WL) in this report is simply calculated as the HLW oxide fraction of the final glass.
} 
to discern between the glass compositions of interest (much less a $1 \%$ change in waste loading). Therefore, the projected operational windows as defined by Peeler and Edwards (2002) are independent of melt rate projections. The latter deficiency imposes the need to assess melt rate for SB3 which should lower the risk of introducing a feed into DWPF that although on paper is very attractive (in terms of waste loading) results in a very difficult feed to process (in terms of melt rate). Implementation and execution of this integrated strategy should provide the basis for developing a decision matrix in which optimum waste throughput could be targeted.

This report focuses on an assessment of melt rate for various frit / sludge combinations. The results provided should not be used as the sole decision-making tool, but they are an important input into the decision making process with respect to the SB3 frit. Objectives for the SB3 melt rate assessment are specified in Section 2.0. Section 3.0 contains a general discussion on the importance of the melt rate assessment to support recent U.S. Department of Energy (DOE) directives of accelerated clean-up missions. Section 4.0 discusses the technical basis from which various SB3 glass systems (i.e., frit and sludge compositions) were selected. The basis for the acid addition strategy used to support the melt rate assessments is provided in Section 5.0. Preparation of the simulated sludge compositions and the procedures used to execute the melt rate assessments are provided in Section 6.0. Results of the melt rate assessments are the primary focus of Section 7.0. Sections 8.0 and 9.0 provide a general summary of the test results and recommendations for future work, respectively. 


\subsection{Objective}

The objective of this task is to assess the influence of frit composition on the melt rate and melting behavior for two separate SB3 washing scenarios (e.g., decants) utilizing the dry-fed melt rate furnace (MRF). The specific decants assessed are Decant \#5 and Decant \#9. The results will provide a basic understanding of the role of glass chemistry on the overall melting process of SB3 ultimately leading to an assessment of the parameters that define optimal waste throughput which may be a compromise between waste loading and melt rate. In addition, these results will be a major input into the frit selection process for SB3. The selection process should not be made based on a single criterion but rather on a collection of criteria that provide insight into both the economics and processability of SB3. It is not the intent of this report to recommend a frit for SB3.

Given melt rate can be influenced by other factors such as waste loading and/or acid addition strategy, the test program was developed to address or isolate (or minimize) these effects to the extent possible in order to assess the impact of frit composition. More specifically, given the potential impact of WL, melt rate assessments were made over a range of WLs $(30-45 \%)$. Although outside the range of acceptability for some systems of interest, the use of "fixed" WLs did allow for direct comparisons among the various frit / sludge combinations. Assessing the impact of WL on melt rate also provides insight into the total waste throughput potential for each system of interest. Given the potential impact of the acid addition strategy to influence the melt rate results, a "fixed" strategy was used in an effort to isolate or minimize this parameter. More specifically, the acid addition strategy remained constant (to the extent possible) for systems based on the same sludge composition (washing scenario).

This work has been prepared to address technical issues discussed in Technical Task Request HLW/DWPF/TTR-01-0027, Rev. 0 (Rios-Armstrong 2002b) and in accordance with the Task Technical and Quality Assurance Plan (Herman, Peeler, and Edwards 2002). 


\subsection{The Incentives}

Recent directives from the DOE have been focused on accelerated clean-up missions for the various sites around the DOE complex. The SRS has developed a program to meet this new directive. With respect to the DWPF, a "vision case" (HLW 2002) has been developed which reduces the overall immobilization campaign by several years. This reduction is based on several parameters; two of which are increases in melt rate and waste loading - which ultimately define the total waste throughput potential for a given system. To support this incentive, the SRTC is focusing on increasing waste loading and/or improving melt rates via strategic glass formulation, changing acid addition strategies, and reassessing process control models. As discussed in Section 1.0, the SB3 frit development team is focused on providing DWPF operational flexibility via large operational windows while maintaining optimum throughput. This objective is consistent with the recent directives from DOE focusing on accelerated clean-up missions.

Glass formulation activities have recently shifted from the strategy of using ubiquitous frits developed to process a number of different sludge batches, to the concept of developing a specific frit for each sludge batch in order to obtain higher waste loadings and/or improved melt rates. In fact, acceptance of this strategy is demonstrated by the TTR to develop a frit specifically for SB3 (Rios-Armstrong 2002b).

One method of supporting site and DOE goals of accelerated cleanup is to improve waste loading. For DWPF, a new liquidus temperature $\left(\mathrm{T}_{\mathrm{L}}\right)$ model has been developed and implemented which has proven to allow higher waste loadings for projected sludge batches (Brown et al. 2001). This new model has been used to establish projected operational windows for various frit / sludge combinations of interest for SB3 (Peeler and Edwards 2002). Additional waste loading increases were projected when implementation of the new $T_{L}$ model was coupled with the concept of alternative frit development. The projected operational windows provided guidance and were used to define targeted WLs for the SB3 melt rate assessments (see Section 4.0 for details). Higher waste loadings may be more beneficial in terms of maximizing waste throughput and meeting the goals of accelerated clean-up. However, although targeting higher waste loadings is a primary objective, other processing constraints are also important - in particular melt rate.

Although every effort was made to consciously develop frit compositions that would lead to enhanced melt rates for SB3 (Peeler and Edwards 2002), the concern is that targeting the maximum WL allowed by model predictions may not lead to optimum melt rate or waste throughput. ${ }^{4}$ In fact, Lorier and McGrier (2002), have shown that for the Frit 320 based system, melt rate actually decreased for the Frit 320-based system with SB2 over the tested WL range see Figure 3-1. The linear melt rate of Frit 200 with SB2 (the baseline for this particular Figure) is also shown merely to indicate that Frit 320 has a higher melt rate up to a WL of $38 \%$.

\footnotetext{
4 Although no models were available to assess melt rate as a function of frit composition, Peeler and Edwards (2002) developed a series of frit composition (i.e., the 400 series - see Appendix A) which not only provided relatively large operating windows but included the general compositional trends observed during the development of Frit 320 for SB2 (Peeler et al. 2001). More specifically, the alkali concentration in the frit was a primary consideration during the SB3 frit development activities given its relation to melt rate - higher alkali content relating to a higher melt rate (Stone and Josephs (2001); Lambert (2001)).
} 


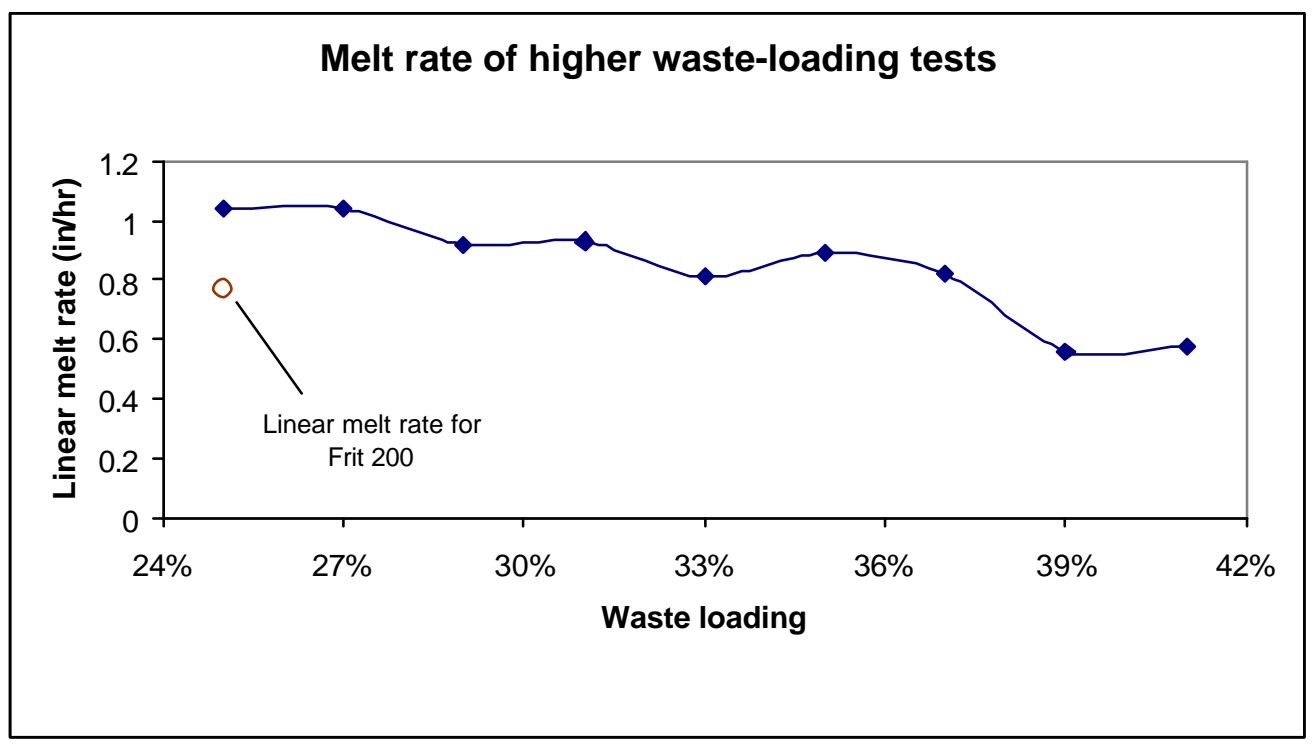

Figure 3-1. Linear Melt Rates for Frit 320 with SB2 as a Function of Waste Loading.

[from Lorier and McGrier (2002)]

However, the notion or concept that reduced melt rates at higher waste loading are unacceptable must be tempered with an evaluation of the total waste throughput. More specifically, during an assessment of the impacts of waste loading on melt rate, decisions on frit selection or targeted waste loading should not be made solely on the relative melt rate. The decision needs to consider the total sludge throughput per unit time.

Lorier and McGrier (2002) demonstrated that the balance between melt rate and WL should be carefully considered as increasing the total waste throughput is a primary goal of the accelerated clean-up mission. Their results indicated that although melt rate diminished as waste loading increased, total waste throughput of Frit 320 with SB2 continued to increase until a critical WL $(\sim 38 \%)$ was reached, after which melt rate and melting behavior diminished below the baseline (Frit 320 at 25\% WL) in terms of throughput (see Figure 3-2).

Given no models are available to assess melt rate, including this assessment as part of the SB3 frit development efforts (and for future sludge batches) is critical to the successful development of an integrated flowsheet. Inclusion of melt rate assessments into the overall strategy will reduce the risk of introducing a feed into DWPF that although on paper is very attractive (in terms of waste loading) results in a very difficult feed to process (in terms of melt rate). However, to support the accelerated clean up mission, the primary focus should be on determining the parameters that define optimal waste throughput, which may be a compromise between waste loading and melt rate.

The practical question that should be asked and addressed is: "Does it really matter that model predictions allow extremely high waste loadings if the DWPF melter processing is hindered or inefficient due to an erratic cold cap behavior or extremely slow melt rate?" To address this issue, the SB3 frit development team has integrated an assessment of melt rate for candidate frit 
compositions into its program in an effort to provide not only relatively high WLs but to maximize waste throughput via a balance between melt rate and WL.

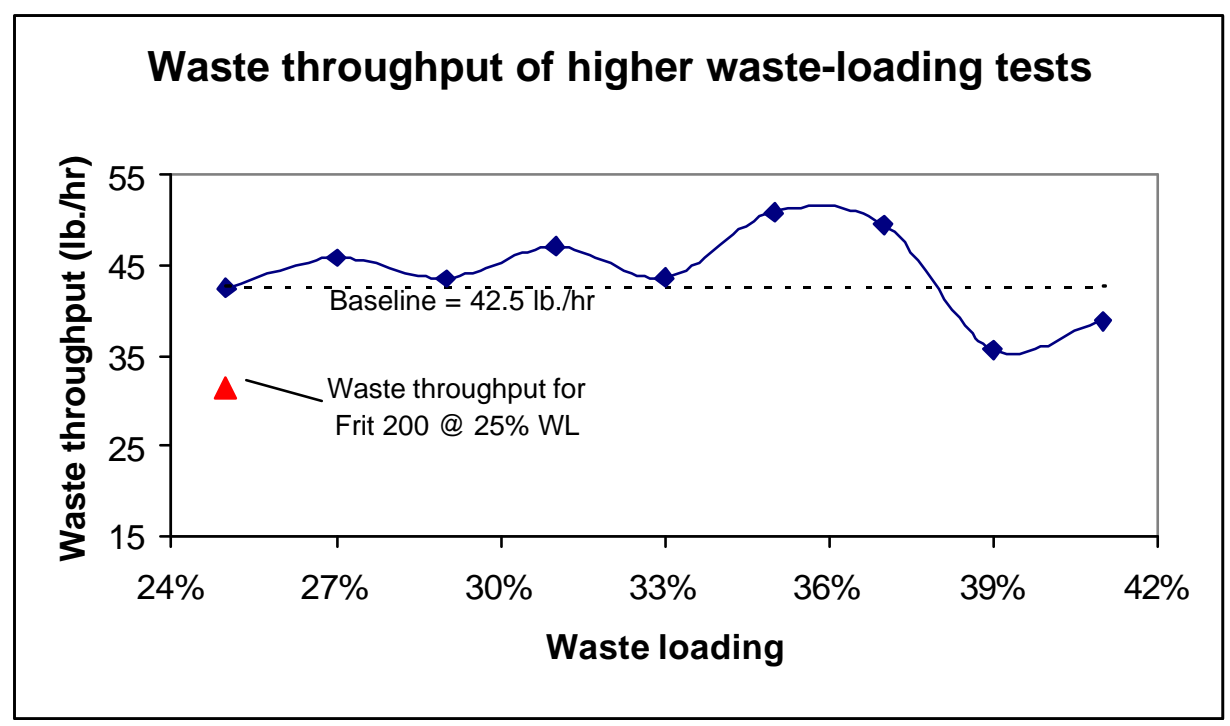

Figure 3-2. Waste Throughput for Frit 320 with SB2 as a Function of Waste Loading [from Lorier and McGrier (2002)]. 


\subsection{Glass System Selection Process}

To establish the glass systems to be evaluated in the melt rate furnace, three primary inputs are required. These are: (1) sludge composition(s), (2) frit composition(s), and (3) targeted WL(s) of interest. Given melt rate can also be influenced by other factors such as acid addition strategy and/or waste loading, the test program was developed to isolate these effects to the extent possible in order to assess the impact of frit composition. In this section, a brief summary of the model-based assessments (Peeler and Edwards 2002) is provided that formed the technical basis from which candidate frits were selected. The specific sludge compositions used to assess melt rate are also defined. Lastly, the technical basis for targeting specific WLs is also provided. The basis for the acid addition strategy for both Decant \#5 and Decant \#9 is discussed in Section 5.0.

\subsection{Sludge Compositions}

Based on input from DWPF and High Level Waste Chemical Processing and Analytical (HLW CP\&A) personnel, the SB3 technical team decided to narrow the focus to span the compositional range bounded by Decant \#5 through Decant \#9. The latter decision was made based on the lack of identifying any significant technical issues during the initial stages of the SB3 flowsheet development activities. Washing the sludge less does have advantages in terms of significant time and labor savings in the pretreatment / retrieval operation. A reduced washing campaign should also result in less water being sent to the evaporators. Conversely, targeting a more washed sludge should reduce the total number of canisters produced by some incremental amount and may minimize components that have potentially negative impacts to either WL or processability (such as $\mathrm{SO}_{4}$ ). A cost-benefit analysis should be performed to fully understand the advantages and disadvantages of selecting a targeted washing scenario. Even though the SB3 team did not have access to a detailed cost-benefit analysis, they elected to narrow the decant / washing focus to span a range covered by Decant \#5 through Decant \#9. The elemental concentrations provided by Elder ${ }^{5}$ were converted to an oxide basis (by multiplying by the appropriate gravimetric factor) and these data are presented in Table 4-1 for Decant \#5 and Decant \#9.

\footnotetext{
${ }^{5}$ Personal communication with H.H. Elder via email dated 7/30/02.
} 
Table 4-1. Projected SB3 Compositions of the Radioactive Decant \#5 and Decant \#9 sludges (oxide basis, wt $\%$ ).

\begin{tabular}{|c|c|c|}
\hline Oxide & Decant \#5 & Decant \#9 \\
\hline $\mathrm{Al}_{2} \mathrm{O}_{3}$ & 13.896 & 15.532 \\
\hline $\mathrm{B}_{2} \mathrm{O}_{3}$ & 0.000 & 0.000 \\
\hline $\mathrm{BaO}$ & 0.193 & 0.215 \\
\hline $\mathrm{CaO}$ & 2.765 & 3.090 \\
\hline $\mathrm{Ce}_{2} \mathrm{O}_{3}$ & 0.268 & 0.299 \\
\hline $\mathrm{Cr}_{2} \mathrm{O}_{3}$ & 0.284 & 0.317 \\
\hline $\mathrm{CuO}$ & 0.153 & 0.170 \\
\hline $\mathrm{Fe}_{2} \mathrm{O}_{3}$ & 30.899 & 34.538 \\
\hline $\mathrm{K}_{2} \mathrm{O}$ & 0.330 & 0.370 \\
\hline $\mathrm{La}_{2} \mathrm{O}_{3}$ & 0.177 & 0.197 \\
\hline $\mathrm{Li}_{2} \mathrm{O}$ & 0.000 & 0.000 \\
\hline $\mathrm{MgO}$ & 0.145 & 0.162 \\
\hline $\mathrm{MnO}_{2}$ & 5.512 & 6.160 \\
\hline $\mathrm{MoO}_{3}$ & 0.000 & 0.000 \\
\hline $\mathrm{Na}_{2} \mathrm{O}$ & 31.323 & 23.240 \\
\hline $\mathrm{NiO}$ & 1.236 & 1.381 \\
\hline $\mathrm{PbO}$ & 0.231 & 0.258 \\
\hline $\mathrm{SiO}_{2}$ & 1.609 & 1.799 \\
\hline $\mathrm{ThO}_{2}$ & 0.110 & 1.123 \\
\hline $\mathrm{TiO}_{2}$ & 2.162 & 2.417 \\
\hline $\mathrm{U}_{3} \mathrm{O}_{8}$ & 7.821 & 8.742 \\
\hline $\mathrm{ZnO}$ & 0.316 & 0.352 \\
\hline $\mathrm{ZrO}_{2}$ & 0.570 & 0.638 \\
\hline Sum & 100.00 & 100.00 \\
\hline
\end{tabular}

Given radioactive capabilities to assess melt rate do not currently exist, a non-radioactive simulant was developed for both Decant \#5 and Decant \#9. Nominal targeted compositions (wt\% calcined oxide basis) for the non-radioactive Decant \#5 and Decant \#9 simulants are listed in Table 4-2. Comparing the target non-radioactive simulants to the projected (radioactive) compositions the major difference observed is the absence of $\mathrm{U}_{3} \mathrm{O}_{8}, \mathrm{ThO}_{2}, \mathrm{Ce}_{2} \mathrm{O}_{3}$, and $\mathrm{PbO}$ in the simulated compositions. All other components were renormalized with these absences. Some components increased by $\sim 3-4 \%$ from Table 4-1 to 4-2, but it is assumed this simulant represents SB3 as closely as possible and the melt rate assessments will be affected equally for each frit.

It also should be noted that the targeted non-radioactive simulants do not account for the potential introduction of a monosodium titanate (MST) stream (e.g., $\mathrm{TiO}_{2}$ is not present in the targeted sludge compositions). Based on the HLW System Plan, Rev. 13 (WSRC 2001), it is anticipated that a limited volume of MST may be blended into SB3. However, given the current uncertainties of when and/or how (e.g., blended over the entire SB3 campaign or spiked into a limited portion of the SB3 campaign) that stream would be blended with SB3; its contribution 
was not accounted for in the melt rate assessment. Given the projected $\mathrm{TiO}_{2}$ concentrations by Elder (see Table 4-1), no significant impact on melt rate is expected.

Table 4-2. Target Compositions of the Non-Radioactive Decant \#5 and Decant \#9 Sludges (oxide basis, wt $\%$ ).

\begin{tabular}{||l|c|c||}
\hline & Decant \#5 & Decant \#9 \\
\hline $\mathrm{Al}_{2} \mathrm{O}_{3}$ & 15.204 & 17.169 \\
\hline $\mathrm{BaO}$ & 0.216 & 0.244 \\
\hline $\mathrm{CaO}$ & 3.091 & 3.503 \\
\hline $\mathrm{Cr}_{2} \mathrm{O}_{3}$ & 0.318 & 0.359 \\
\hline $\mathrm{CuO}$ & 0.171 & 0.193 \\
\hline $\mathrm{Fe}_{2} \mathrm{O}_{3}$ & 34.215 & 38.714 \\
\hline $\mathrm{K}_{2} \mathrm{O}$ & 0.368 & 0.419 \\
\hline $\mathrm{La}_{2} \mathrm{O}_{3}$ & 0.198 & 0.223 \\
\hline $\mathrm{MgO}$ & 0.162 & 0.184 \\
\hline $\mathrm{MnO}_{2}$ & 6.162 & 6.983 \\
\hline $\mathrm{Na}_{2} \mathrm{O}$ & 34.753 & 25.991 \\
\hline $\mathrm{NiO}$ & 1.382 & 1.566 \\
\hline $\mathrm{P}_{2} \mathrm{O}_{5}$ & 0.020 & 0.030 \\
\hline $\mathrm{SiO}_{2}$ (non-sand) & 1.270 & 1.070 \\
\hline $\mathrm{Sand}$ & 0.530 & 0.970 \\
\hline $\mathrm{ZnO}$ & 0.353 & 0.399 \\
\hline $\mathrm{ZrO} \mathrm{Zn}_{2}$ & 0.637 & 0.723 \\
\hline $\mathrm{Coal}$ & 0.950 & 1.260 \\
\hline & & \\
\hline Sum & 100.00 & 100.00 \\
\hline
\end{tabular}

\subsection{Frit Selection Process}

Given the decision by the SB3 Technical Team to focus on Decant \#5 and Decant \#9, the list of available frit compositions (either existing or from the 400 series) was limited based on the model-based predictions (Peeler and Edwards 2002). For example, the use of Frit 320 for either of these decants is prohibited due to predictions of durability. The high alkali content of both the frit and the less-washed sludges is the primary driver for the unacceptable predictions. The model-based assessments by Peeler and Edwards (2002) provide valuable information with respect to how the projected operational windows respond to compositional variation around a nominal sludge composition for various frits. The Nominal and Variation Stage assessments allowed candidate frit compositions to be screened with respect to their potential application to SB3. For example, a frit that did not provide an operational window (for a specific sludge composition or compositional region) was not considered as a candidate in the assessment of melt rate given the models would ultimately not allow DWPF to process. Figure 4-3 lists the nominal compositions of candidate frits tested in this study.

Tables 4-4 and 4-5 summarize the Phase 1 (Nominal) and Phase 2 (Variation) stage assessments for candidate frits for Decant \#5 and Decant \#9, respectively (from Peeler and Edwards, 2002). It 
should be noted that there are candidate frits for both Decant \#5 and Decant \#9, and that model predictions indicate relatively large operational windows for select frits. The assessments also demonstrate the ability of select frits to tolerate the anticipated composition variation $(\sim \pm 10 \%)$ around the nominal sludge composition. A brief summary of the Decant \#5 and Decant \#9 assessments performed by Peeler and Edwards (2002) is provided below to establish the technical basis from which the frit down-select process was based. The down-select process was a detailed review of all candidate frits with respect to operational window size and tolerance to compositional variation to identify those that may lead to enhanced melt rates for SB3. Based on this review, a limited set of primary frit candidates was identified to support assessments of melt rate.

\subsubsection{Decant \#5: Phase 2 Assessment}

Given the high alkali concentration associated with the nominal Decant \#5, when a $\pm 10 \%$ variation in each sludge component is considered, the extremely high alkali-based frits (such as Frit 320, 416, 411, and 412) do not have projected operational windows over which all the extreme vertices (EVs) can be processed. ${ }^{6}$ Model predictions that exceed the durability and low viscosity acceptance constraints eliminate these frits from further consideration for these specific washing scenarios. Any use of these frits in the SB3 melt rate assessment is strictly of scientific interest to assess the compositional trends observed by Stone and Josephs (2001) with respect to alkali and melt rate.

As the frit compositions become more refractory (composition contains less alkali), the tolerance or robustness to the applied compositional variation generally increases. A cursory review of the projected windows associated with the Phase 2 Variation Stage for Decant \#5 assessment support this latter statement. A positive response from the three metrics ${ }^{7}$ (as shown in Figures 4-4 and 45 ) used to assess the degree of tolerance to compositional uncertainties is observed. It should be noted that Frit 202 is one of the less refractory frits being considered for Decant \#5, which could have a major impact during the frit selection process. For example, possible scenarios would include to 1) utilize Frit 202 for Decant \#5 regardless of melt rate or throughput issues recognizing the relatively small projected operational windows, and/or 2) recommend a more advanced-washed sludge (higher decant) so frit operational uncertainties are minimized (if not eliminated).

No WL or WL interval exists over which all EVs can be processed with Frit 202. A more detailed review of the second and third metrics of Table 4-4 indicates that only $70 \%$ of the EVs can be processed at some WL with $\sim 52 \%$ of those having a minimum $5 \%$ window. The results for Frits 420, 421, 422, and 423 are somewhat more positive but still less than perfect (when compared to other frits in Table 4-4). The WL ranges over which all the EVs could be processed

\footnotetext{
${ }^{6}$ The extreme vertices (EVs) for a particular sludge view are the "corner points" of the region determined by applying the $\pm 10 \%$ variation about the nominal composition for that sludge view. The corresponding centroid for the sludge view is simply the arithmetic average of these EVs.

${ }^{7}$ The first metric is the waste loading interval over which all of the EVs and the centroid SB3 sludge compositions were deemed acceptable based on the established acceptance criteria. The second metric defines the percentage of the EVs and centroid that yield an acceptable glass at some waste loading of interest. The third metric builds upon the second and serves as the measure of the percentage of the EVs and centroid that yield an acceptable glass over a minimum waste loading range of $5 \%$ within the $25-60 \%$ window being evaluated.
} 
for these frits is roughly a $2-4 \%$ window (all being in the mid-to-high 30 's). Subsequent metrics indicate a less than perfect response to the compositional variation applied.

The Phase 2 (Variation Stage) Decant \#5 assessments for Frits 406, 405, 409, and 410 are very similar and provide feedback into the effect of the compensations required to handle the high concentration and variation of alkali in the sludge. The Decant \#5 EVs could be processed by either of these frits over a relatively large WL interval. Waste loading intervals of $36-40 \%, 36-$ $39 \%, 36-41 \%$, and $36-41 \%$, respectively, are projected indicating a relatively high degree of robustness for these frits. The second and third metrics are also very similar yielding $100 \%$ values which indicate that all $927 \mathrm{EVs}$ could be processed at some WL with each having a minimum WL range of 5\%. In fact, the minimum WL ranges are $6 \%$ or $9 \%$ depending upon the frit. Assuming all other factors equal, the frit selection process would favor the latter four frits given the model-based assessment responses. Utilization of a refractory frit may not be advantageous from a melt rate perspective - an assessment to be made in this study.

\subsubsection{Decant \#9: Phase 2 Assessment}

Table 4-5 summarizes the model-based Phase 2 assessments for the primary frits for Decant \#9. Frit 202 should be considered a candidate frit for the compositional region covered by the Decant \#9 EVs. All of the Decant \#9 EVs can be processed over a WL range of $33-36 \%$ with the minimum WL range being 9\% for each EV. These results suggest that Frit 202 is extremely robust to the compositional variation presented by the EVs associated with Decant \#9.

The modifications made to Frit 202 (e.g., Frit 420 and Frit 421) also demonstrate flexibility to process the Decant \#9 EVs with WL projections of $37-38 \%$ and $34-37 \%$, respectively. The second and third metrics indicate that Frit 421 may have a slight advantage over Frit 420 based on model predictions.

The "higher" (Frits 411, 416, and 320) and "lower" (Frits 409 and 410) alkali containing frits are less attractive given their response to the Phase 2 Variation Stage assessments. Although the Nominal Stage assessments indicate relatively large operating windows (with the exception of Frit 320 in which there was no window), only Frit 411 possesses a WL range over which all the EVs could be processed.

The assessment of Frits 422 and 423 (intermediate alkali containing frits) indicates both respond extremely well to the applied compositional variation. The projected WL ranges over which all the EVs could be processed are $33-37 \%$ and $32-37 \%$, respectively. With a minimum WL interval of $6 \%$ and $10 \%$, Frits 422 and 423 should be considered primary candidates within this compositional region. 


\subsubsection{The Down-Select Process}

A down-selection process was utilized to select the 400-series frits most likely to succeed with Decant \#5 and/or Decant \#9. An initial frit down selection occurred based on the model-based assessments (i.e., those frits that indicated relatively large processing windows and had a positive response on the ability to handle compositional variation as a function of various washing scenarios). A second cut was based on similarities in composition between frits and insight from Stone and Josephs (2001) regarding the compositional trends thought to improve melt rate.

For example, consider Frit 409 and Frit 410 where the only distinction is a $1 \%$ difference in $\mathrm{Li}_{2} \mathrm{O}$ and $\mathrm{Na}_{2} \mathrm{O}$ concentrations. The $\mathrm{Li}_{2} \mathrm{O}$ and $\mathrm{Na}_{2} \mathrm{O}$ target concentrations for Frit 409 are $4.0 \%$ and $6.0 \%$, respectively. The $\mathrm{Li}_{2} \mathrm{O}$ and $\mathrm{Na}_{2} \mathrm{O}$ concentrations for Frit 410 are both 5.0\%. Given the similar compositions and recognizing that the MRF probably would not be able to discern a melt rate difference between these two systems, one frit was selected to essentially represent both compositions. In this case, Frit 409 was selected given the enhanced $\mathrm{Na}_{2} \mathrm{O}$ concentration in Frit 320 to improve melt rate for SB2. These two frits have essentially the same projected operational windows and robustness to compositional variation for Decant \#5 (see Table 4-4). Table 4-3 summarizes the frit compositions used in the MRF assessments.

Table 4-3. Nominal Compositions of Candidate Frits (in wt $\%$ on an oxide basis).

\begin{tabular}{||c|c|c|c|c|c|c|c|c|c||}
\hline & $\begin{array}{c}\text { Frit } \\
\mathbf{2 0 2}\end{array}$ & $\begin{array}{c}\text { Frit } \\
\mathbf{3 2 0}\end{array}$ & $\begin{array}{c}\text { Frit } \\
\mathbf{4 0 5}\end{array}$ & $\begin{array}{c}\text { Frit } \\
\mathbf{4 0 9}\end{array}$ & $\begin{array}{c}\text { Frit } \\
\mathbf{4 1 1}\end{array}$ & $\begin{array}{c}\text { Frit } \\
\mathbf{4 1 6}\end{array}$ & $\begin{array}{c}\text { Frit } \\
\mathbf{4 2 1}\end{array}$ & $\begin{array}{c}\text { Frit } \\
\mathbf{4 2 2}\end{array}$ & $\begin{array}{c}\text { Frit } \\
\mathbf{4 2 3}\end{array}$ \\
\hline $\mathrm{Al}_{2} \mathrm{O}_{3}$ & - & - & - & - & 1 & 1 & 1 & - & - \\
\hline $\mathrm{B}_{2} \mathrm{O}_{3}$ & 8 & 8 & 20 & 8 & 8 & 8 & 10 & 8 & 10 \\
\hline $\mathrm{Li}_{2} \mathrm{O}$ & 7 & 8 & 5 & 4 & 5 & 8 & 5 & 8 & 8 \\
\hline $\mathrm{Na}_{2} \mathrm{O}$ & 6 & 12 & - & 6 & 12 & 11 & 7 & 3 & 3 \\
\hline $\mathrm{SiO}_{2}$ & 77 & 72 & 75 & 82 & 74 & 72 & 77 & 81 & 79 \\
\hline $\mathrm{MgO}$ & 2 & - & - & - & - & - & - & - & - \\
\hline & & & & & & & & & \\
\hline Total & 100 & 100 & 100 & 100 & 100 & 100 & 100 & 100 & 100 \\
\hline
\end{tabular}


Table 4-4. Primary Frit Candidates for Decant \#5.

\begin{tabular}{||l|c|c|c|c|c|c|c|c|c|c|c|c||}
\hline \hline & Decant \#5 & Frit 406 & Frit 405 & Frit 409 & Frit 410 & Frit 411 & Frit 416 & Frit 420 & Frit 421 & Frit 422 & Frit 423 & Frit 202 \\
\hline Nominal & WL (nominal) & $33-51$ & $31-46$ & $33-50$ & $32-50$ & None & None & $30-45$ & $30-44$ & $31-46$ & $31-44$ & $33-39$ \\
\hline Variation & WL all EVs & $36-40$ & $36-39$ & $36-41$ & $36-41$ & --- & --- & $34-36$ & $34-35$ & $36-39$ & $36-37$ & None \\
\hline & \%Vs at some WL & $100.0 \%$ & $100.0 \%$ & $100.0 \%$ & $100.0 \%$ & --- & --- & $100.0 \%$ & $100.0 \%$ & $100.0 \%$ & $100 \%$ & $70.0 \%$ \\
\hline & $\begin{array}{c}\text { WL range of 5\% or } \\
\text { greater }\end{array}$ & $100.0 \%$ & $100.0 \%$ & $100.0 \%$ & $100.0 \%$ & --- & --- & $92.1 \%$ & $87.8 \%$ & $95.7 \%$ & $90.2 \%$ & $51.6 \%$ \\
\hline & Minimum WL range & $6 \%$ & $9 \%$ & $6 \%$ & $6 \%$ & --- & --- & --- & --- & --- & --- & --- \\
\hline
\end{tabular}

Table 4-5. Primary Frit Candidates for Decant \#9.

\begin{tabular}{||c|c|c|c|c|c|c|c|c|c|c|c|c||}
\hline \hline & Decant \#9 & Frit 409 & Frit 410 & Frit 411 & Frit 420 & Frit 421 & Frit 422 & Frit 423 & Frit 202 & Frit 412 & Frit 416 & Frit 320 \\
\hline Nominal & WL (nominal) & $39-44$ & $38-44$ & $26-46$ & $33-46$ & $30-45$ & $30-45$ & $28-45$ & $29-44$ & $28-46$ & $26-38$ & None \\
\hline Variation & WL all EVs & None & None & $30-38$ & $37-38$ & $34-37$ & $33-37$ & $32-37$ & $33-36$ & $32-35$ & None & None \\
\hline & \%Vs at some WL & $66.1 \%$ & $76.4 \%$ & $100 \%$ & $100.0 \%$ & $100.0 \%$ & $100.0 \%$ & $100.0 \%$ & $100.0 \%$ & $100.0 \%$ & $58.5 \%$ & $31.1 \%$ \\
\hline & $\begin{array}{c}\text { WL range of 5\% or } \\
\text { greater }\end{array}$ & $50.0 \%$ & $53.4 \%$ & $100 \%$ & $94.4 \%$ & $100.0 \%$ & $100.0 \%$ & $100.0 \%$ & $100.0 \%$ & $99.9 \%$ & $54.0 \%$ & $28.8 \%$ \\
\hline & Minimum WL range & - & - & $9 \%$ & - & $6 \%$ & $6 \%$ & $10 \%$ & $9 \%$ & - & - & - \\
\hline
\end{tabular}




\subsection{Waste Loading}

To directly compare the effect of frit composition on melt rate, the need to select common waste loadings for each frit / sludge system was essential. This stems from the diminishing response of melt rate as WL increased for the Frit 320 / SB2 system as observed by Lorier and McGrier (2002). The use of common waste loadings should provide a sound technical basis for two assessments, the first being a direct comparison of melt rate between frit-based systems at a constant waste loading, and the second being the impact of waste loading changes on melt rate within a specific system. The latter provides insight into total waste throughput potential for a particular frit / sludge system. Table 4-6 summarizes the Measurement Acceptability Region (MAR) assessments performed by Peeler et al. (2002b) for the primary frit / sludge systems. The SB3 melt rate team selected WLs of 30,35 , and $40 \%$ as the basis for the melt rate tests as most of the primary frit / sludge systems have operational windows that span this WL range. For example, consider the Frit 420 / Decant \#5 system. The projected operating window for this system is $30-43 \mathrm{wt} \% \mathrm{WL}$. Assessing melt rate at 30,35, and $40 \% \mathrm{WL}$ will essentially span the acceptable WL range and provide valuable information with respect to trends in total waste throughput as a function of WL.

It is recognized that electing to use common and fixed waste loadings provides some disadvantages. One disadvantage is the fact that the acceptable WL intervals (as defined in Table 4-6) for the various frit / sludge systems are not consistent. Therefore, the use of common waste loadings in some systems does not provide an assessment at the "bounding" WL (lower and upper WL limits that define the projected operational window) as defined by model predictions. This could lead to an assessment of melt rate in a compositional region that would not be allowed in the DWPF (based on model predictions) or not provide full coverage at the upper WLs limits of interest. For example, consider the two Frit 202 based systems. When coupled with Decant \#5, the projected operational window based on MAR predictions is $33-37 \%$. Based on model predictions, homogeneity (or lack thereof) limits access to WLs less than $33 \%$ while durability predictions restrict access to WLs higher than $37 \%$. Therefore, including melt rate assessments at $30 \%$ and $40 \%$ may be questionable given they led to unacceptable products based on model predictions. However, the proposed WLs of 30,35, and $40 \%$ do bound the anticipated processing region over which the effect of WL on melt rate can be viewed.

The use of 30\% and 40\% WLsfor the Frit 202 / Decant \#9 melt rate tests are also non-bounding tests (MAR predictions allow for a $29-45 \% \mathrm{WL}$ window). Of particular interest is the gap between $41-45 \%$ WL that would not be covered. Although the use of constant WLs to assess melt rate for each frit / sludge system is not perfect, the melt rate information obtained can be used as a guide to understand the impacts of frit composition and WL on melt rate and should provide the template for this relationship from which melt rate interpolations could be made (albeit with some risk). This strategy does provide a technical basis from which direct comparisons can be made to assess the impact of frit composition on melt rate - the objective of this task. 
Immobilization Technology Section

WSRC-TR-2003-00027

Savannah River Technology Center

Rev. 0

Westinghouse Savannah River Company

Table 4-6. Summary of Waste Loading Ranges for Select Frit / Sludge Combinations Using the MAR Criteria (from Peeler et al. 2002b).

\begin{tabular}{|c|c|c|c|c|c|c|c|c|c|}
\hline & & Frit 202 & Frit 409 & Frit 410 & Frit 420 & Frit 421 & Frit 422 & Frit 423 & Frit 411 \\
\hline \multirow[t]{2}{*}{ Decant \#5 } & WL (nominal) & $33-37$ & $34-48$ & $33-48$ & $30-43$ & $30-41$ & $31-45$ & $31-43$ & - \\
\hline & Upper limit & PCT & PCT & PCT & PCT & PCT & Low Vis & Low Vis & - \\
\hline \multirow[t]{3}{*}{ Decant \#9 } & WL (nominal) & $29-45$ & - & - & $35-47$ & $32-47$ & $31-46$ & $28-46$ & $26-45$ \\
\hline & Lower limit & Homog & - & - & High Vis & High Vis & High Vis & High Vis & Homog \\
\hline & Upper limit & $\mathrm{T}_{\mathrm{L}}$ & - & - & $\mathrm{T}_{\mathrm{L}}$ & $\mathrm{T}_{\mathrm{L}}$ & $\mathrm{T}_{\mathrm{L}}$ & $\mathrm{T}_{\mathrm{L}}$ & Low Vis \\
\hline
\end{tabular}




\subsection{Acid Addition Strategy}

The technical basis for the acid addition strategy is discussed in this section. Given that the acid addition strategy has been a focal point of improving melt rate in previous studies (e.g., Stone and Josephs 2001; Lambert et al. 2001), the impact of the acid addition strategy should be minimized, eliminated, or at least held constant for this study. Use of a constant acid addition strategy should eliminate (or at least minimize) any potential overwhelming impacts of the acid addition strategy on melt rate so a relative measure of the effect of frit composition on melt rate can be obtained. More specifically, given the objective of this task, the SB3 frit development team did not want the acid addition strategy (which is in parallel development for SB3 - see Jantzen 2002; Herman et al. 2002a; Herman 2002a, Herman 2002b) to suppress or overwhelm this assessment. The desire was to utilize an acid addition and redox control strategy that completed all required reactions (e.g., nitrite destruction) but remained conservative (with respect to the total quantity) given an operational window was available. It is recognized that the strategy being utilized was based on the state of understanding at the time this task was initiated and changes were probable as new data were generated to refine model algorithms.

Observations made during the Tank 8 simulant testing with oxalate were used to provide a preliminary target for total acid to be added (Herman et al. 2002a). This acid total was divided between nitric and formic acids using an interim (theoretical) algorithm for redox control (Jantzen 2002). This redox algorithm also made certain assumptions about the carbon valence states before and after melting of the waste-frit combination.

The interim redox algorithm was a modification of the current DWPF redox algorithm. The current DWPF redox algorithm is:

$$
\begin{aligned}
& \frac{F e^{2+}}{\Sigma F e}=0.217+\left(0.253 * \text { melter feed formate molarity } * \frac{45 \%}{\text { melter feed wt. } \% \text { total solids }}\right)- \\
& \left(0.739 * \text { melter feed nitrate molarity } * \frac{45 \%}{\text { melter feed } w t . \% \text { total solids }}\right) .
\end{aligned}
$$

The modified algorithm replaced melter feed formate molarity with the following sum:

$$
\text { melter feed formate molarity + melter feed oxalate molarity }+2 * \text { melter feed coal molarity. }
$$

The electron balance premise for the modified algorithm was that each carbon in oxalate was only half as reducing as the carbon in formate, while the carbon in coal was twice as reducing as the carbon in formate. While this algorithm was based on proposed chemical reactions, closed crucible testing with SB3 simulant feeds has shown that additional modifications to the algorithm will be necessary to predict the glass redox. The nominal target for $\mathrm{Fe}^{+2} \Sigma \mathrm{Fe}$ was a value of 0.20 . The assumed waste loading was $30 \%$ sludge oxides in glass (used in calculating the melter feed molarities based on sludge nitrate, oxalate, and coal along with the formic acid and nitric acid additions, less the usual reaction loss of formate or formation of nitrate).

The current DWPF 100\% stoichiometric acid demand (minimum total moles of acid required for processing) is calculated by: 


$$
\text { moles acid }=V_{S} *\left[N_{1}+\rho_{S} *\left(\frac{0.75 * N_{2}}{46.007}+\frac{1.2 * N_{3}}{54.938}+\frac{N_{4}}{200.6}+\frac{2 * N_{5}}{12.01}\right)\right]
$$

where:

$\begin{array}{ll}V_{S} & \text { is the slurry volume } \\ \rho_{S} & \text { is the slurry density } \\ N_{1} & \text { is the base equivalents from a 30:1 dilution titration of the slurry to pH } 7 \\ N_{2} & \text { is the mass of nitrite ion per unit mass slurry } \\ N_{3} & \text { is the mass of Mn(IV) per unit mass slurry } \\ N_{4} & \text { is the mass of mercury per unit mass slurry } \\ N_{5} & \text { is the mass of inorganic carbon per unit mass slurry }\end{array}$

The calculated total of the moles of acid has been historically multiplied by a factor such as $125 \%$ or $137.5 \%$ to ensure adequate nitrite destruction. This factor compensates for inaccuracies in the equation itself in addition to covering potential analytical errors in the input measurements.

This equation was modified for runs with significant oxalate content as follows (Herman 2002a; Herman 2002b):

where:

$$
\text { moles acid }=V_{S} *\left[N_{1}+\rho_{S} *\left(\frac{1.5 * N_{2}}{46.007}+\frac{1.2 * N_{3}}{54.938}+\frac{N_{4}}{200.6}+\frac{1.5 * N_{5}}{12.01}+\frac{0.5 * N_{6}}{88.02}\right)\right]
$$

$\mathrm{N}_{6} \quad$ is the mass of total oxalate ion per unit mass slurry.

The nitrite ion coefficient was increased from 0.75 to 1.5 based on the results obtained during the analysis of the Tank 8 Sludge Receipt and Adjustment Tank (SRAT) runs (Koopman et al. 2003). These runs had $25-75 \%$ of the postulated Tank 7 oxalate remaining in the washed sludge. A factor was added for oxalate of 0.5 moles of acid per mole of oxalate. This was also based on the Tank 8 SRAT runs. The stoichiometric equation at this point predicted too large an acid requirement compared to experimental results. The coefficient on total inorganic carbon (TIC) was arbitrarily reduced from 2 to 1.5 to compensate. This also served to offset the previously identified issue of partial double counting between the base equivalents and TIC terms in the current algorithm (Koopman et al. 2003). Again, this calculation was the best available to support the SRAT runs for the SB3 melt rate test program (Lorier 2002a; Lorier 2002b). ${ }^{8}$

The target inputs given in Table 6-5 were used to prepare acid calculations for Decant \#5 and Decant \#9 using the modified algorithm for moles of acid above. The target batch size was 16.65 $\mathrm{kg}$ trimmed sludge. The calculated total moles were increased to $110 \%$ for the actual runs. The acid moles were divided between nitric and formic acid using the interim redox relationship given above.

${ }^{8}$ These runs occurred about a month before nearly equivalent sludges were run in the smaller, 4-liter scale to better determine acid requirements. 


\subsection{Experimental}

This section describes the preparation of the sludge simulants, the procedures used to fabricate and analyze both the target sludge and frit compositions, and the test conditions used in the melt rate furnace.

\subsection{Preparation of Decant \#5 and Decant \#9 Sludge Simulants}

Two non-radioactive sludge simulants were prepared for this testing representing two projected wash endpoint compositions (Decant \#5 and Decant \#9 - see Table 4-1). The two sludge simulants were prepared from a common starter simulant. The starter simulant contained the primary elemental components, except for the majority of the sodium salts and most of the minor species. Missing species were added to achieve target values for anions such as nitrite, oxalate, and sulfate and to account for a few additional minor cations. It is important to note that $\mathrm{Na}_{2} \mathrm{SO}_{4}$ was used as the source of $\mathrm{SO}_{3}{ }^{-}$for each sludge. Including $\mathrm{SO}_{3}{ }^{-}$will provide an assessment of the potential to exceed the $\mathrm{SO}_{3}{ }^{-}$or $\mathrm{Na}_{2} \mathrm{SO}_{4}$ limits in DWPF at the higher WLs being targeted. In the future, the amount of $\mathrm{SO}_{3}{ }^{-}$present can be calculated based on the $\mathrm{WL}$, so the risk of excess $\mathrm{SO}_{3}{ }^{-}$ being present can be avoided.

Table 6-1 summarizes the trim chemicals used to target the nominal Decant \#5 and Decant \#9 compositions. Table 6-2 provides a comparison of the target and measured compositions for both decants. Sludge compositions were measured by the Savannah River Technology Center Mobile Laboratory (SRTC-ML) using inductively coupled plasma - atomic emission spectroscopy (ICP-AES) and ion chromatography (IC) analysis. Overall, comparisons between the measured and targeted compositions suggest that there were no significant problems in the batching of these two simulants with the possible exception of $\mathrm{MnO}_{2}$. It should be noted that the measured composition of $\mathrm{MnO}_{2}$ for Decant \#5 was twice the target composition. This amount could have an adverse affect on melting behavior. However, it is assumed that the influence of the $\mathrm{MnO}_{2}$ on melting behavior would be the same for all tested frits, and an assessment (relative) of melt rate could still be obtained, although the validity of this assumption cannot be confirmed by the limited tests of this study. 
Table 6-1. Compositions (oxide basis, wt\%) of Tested Decants (Pre- and Post-Addition of Trim Chemicals).

\begin{tabular}{|c|c|c|c|c|}
\hline Species & Initial (Pre-Trim) & "Trim Chemical & \multicolumn{2}{|c|}{ Post-Trim } \\
\hline & & & Decant \#5 & Decant \#9 \\
\hline $\mathrm{A} 1$ & $19.90 \%$ & & $15.24 \%$ & $18.53 \%$ \\
\hline $\mathrm{Ba}$ & $0.27 \%$ & & $0.21 \%$ & $0.25 \%$ \\
\hline $\mathrm{Ca}$ & $3.95 \%$ & & $3.03 \%$ & $3.66 \%$ \\
\hline $\mathrm{Cr}$ & $0.00 \%$ & $\mathrm{Cr}_{2} \mathrm{O}_{3}$ & $0.31 \%$ & $0.39 \%$ \\
\hline $\mathrm{Cu}$ & $0.21 \%$ & & $0.17 \%$ & $0.21 \%$ \\
\hline $\mathrm{Fe}$ & $43.88 \%$ & & $33.59 \%$ & $40.83 \%$ \\
\hline $\mathrm{K}$ & $0.23 \%$ & $\mathrm{KNO}_{3}$ & $0.28 \%$ & $0.34 \%$ \\
\hline $\mathrm{La}$ & $0.00 \%$ & $\mathrm{La}_{2} \mathrm{O}_{3}$ & $0.11 \%$ & $0.11 \%$ \\
\hline $\mathrm{Mg}$ & $0.41 \%$ & & $0.31 \%$ & $0.39 \%$ \\
\hline $\mathrm{Mn}$ & $7.37 \%$ & & $5.64 \%$ & $6.87 \%$ \\
\hline $\mathrm{Na}$ & $1.43 \%$ & $\mathrm{Na}_{2} \mathrm{C}_{2} \mathrm{O}_{4}$ & $36.66 \%^{(b)}$ & $22.77 \%^{(b)}$ \\
\hline & & $\mathrm{Na}_{2} \mathrm{CO}_{3}$ & & \\
\hline & & $\mathrm{NaNO}_{2}$ & & \\
\hline & & $\mathrm{NaNO}_{3}$ & & \\
\hline & & $\mathrm{NaOH}$ & & \\
\hline & & $\mathrm{Na}_{2} \mathrm{SO}_{4}$ & & \\
\hline $\mathrm{Ni}$ & $1.63 \%$ & & $1.25 \%$ & $1.51 \%$ \\
\hline $\mathrm{P}$ & $0.03 \%$ & & $0.02 \%$ & $0.03 \%$ \\
\hline $\mathrm{Si}$ & $2.35 \%$ & $\mathrm{SiO}_{2}$ & $1.80 \%$ & $2.21 \%$ \\
\hline $\mathrm{Zn}$ & $0.45 \%$ & & $0.34 \%$ & $0.42 \%$ \\
\hline $\mathrm{Zr}$ & $0.82 \%$ & & $0.64 \%$ & $0.77 \%$ \\
\hline Coal & $0.00 \%$ & $\mathrm{C}$ & (a) & (a) \\
\hline Sand & $0.00 \%$ & Sand & (a) & (a) \\
\hline DIW & -- & $\mathrm{H}_{2} \mathrm{O}$ & --- & --- \\
\hline
\end{tabular}

(a) Amounts of coal and sand added during SRAT process.

(b) Indicates total sodium. 
Table 6-2. Sludge Target and Measured Compositions of Decants \#5 and \#9 (oxide basis, wt\%).

\begin{tabular}{|c|c|c|c|c|}
\hline Oxide & $\begin{array}{c}\text { Target } \\
\text { Decant \#5 }\end{array}$ & $\begin{array}{l}\text { Measured } \\
\text { Decant \#5 }\end{array}$ & $\begin{array}{c}\text { Target } \\
\text { Decant \#9 }\end{array}$ & $\begin{array}{l}\text { Measured } \\
\text { Decant \#9 }\end{array}$ \\
\hline $\mathrm{Al}_{2} \mathrm{O}_{3}$ & 15.20 & 14.55 & 17.18 & 18.82 \\
\hline$\overline{\mathrm{BaO}}$ & 0.22 & 0.17 & 0.24 & 0.23 \\
\hline $\mathrm{CaO}$ & 3.09 & 2.79 & 3.50 & 3.80 \\
\hline $\mathrm{Cr}_{2} \mathrm{O}_{3}$ & 0.32 & 0.54 & 0.36 & 0.65 \\
\hline $\mathrm{CuO}$ & 0.17 & 0.12 & 0.19 & 0.18 \\
\hline $\mathrm{Fe}_{2} \mathrm{O}_{3}$ & 34.22 & 29.93 & 38.72 & 38.69 \\
\hline $\mathrm{K}_{2} \mathrm{O}$ & 0.37 & 0.18 & 0.42 & 0.35 \\
\hline $\mathrm{La}_{2} \mathrm{O}_{3}$ & 0.20 & 0.16 & 0.22 & 0.21 \\
\hline $\mathrm{MgO}$ & 0.16 & 0.23 & 0.18 & 0.30 \\
\hline $\mathrm{MnO}_{2}$ & 6.16 & 11.17 & 6.98 & 7.06 \\
\hline $\mathrm{Na}_{2} \mathrm{O}$ & 34.75 & 35.11 & 25.99 & 23.06 \\
\hline $\mathrm{NiO}$ & 1.38 & 0.96 & 1.57 & 1.23 \\
\hline $\mathrm{P}_{2} \mathrm{O}_{5}$ & 0.02 & $\mathrm{~N} / \mathrm{A}^{(\mathrm{a})}$ & 0.03 & N/A \\
\hline $\mathrm{SiO}_{2}$ (non-sand) & 1.27 & - & 1.07 & - \\
\hline Sand & 0.53 & - & 0.97 & - \\
\hline Total $\mathrm{SiO}_{2}$ & - & 3.61 & - & 3.29 \\
\hline $\mathrm{ZnO}$ & 0.35 & 0.31 & 0.40 & 0.40 \\
\hline $\mathrm{ZrO}_{2}$ & 0.64 & 0.54 & 0.72 & 0.70 \\
\hline Coal & 0.95 & N/A & 1.26 & N/A \\
\hline Total & 100.00 & (b) & 100.00 & (b) \\
\hline
\end{tabular}

(a) N/A stands for "not analyzed".

(b) Not totaled because coal and $\mathrm{P}_{2} \mathrm{O}_{5}$ not analyzed for.

Target sand is listed separately from target silica in Tables 6-1 and 6-2. The target silica wt. \% represents silica from sources other than sand. The wt. \% for sand assumes the sand is $100 \%$ $\mathrm{SiO}_{2}$. The sand was from the same vendor as the sand filter added to Tank 7. ${ }^{9}$ The nominal sand size was about 0.4-0.5 mm diameter. Total silica represents the ICP-AES result for all Si that was dissolved in the sample. Anthracite coal approximately $0.6-0.8 \mathrm{~mm}$ in diameter was also added to both sludge simulants. It was also obtained from the same sand filter vendor as the coal added to Tank 7. Table 6-3 lists selected target anion concentrations of the two simulants along with corresponding measured analytical results. The measured compositions of oxalate listed in Table 6-3 are $~ 15 \%$ bias high due to a bad oxalate standard, which resulted in a poor calibration curve. It should also be noted that the values listed in Table 6-2 for coal and sand are nominal compositional levels.

\footnotetext{
${ }^{9}$ Graver supplied the Monoscour automatic filter to the reactor facilities. The filter had approximately $142.5 \mathrm{cu}$. ft. of both anthracite and fine sand.
} 
Table 6-3. Anion Target and Measured Compositions of Decants \#5 and \#9.

\begin{tabular}{||l|c|c|c|c||}
\hline \hline & $\begin{array}{c}\text { Target } \\
\text { Decant \#5 } \\
(\mathrm{mg} / \mathrm{kg})\end{array}$ & $\begin{array}{c}\text { Measured } \\
\text { Decant \#5 } \\
(\mathrm{mg} / \mathrm{kg})\end{array}$ & $\begin{array}{c}\text { Target } \\
\text { Decant \#9 } \\
(\mathrm{mg} / \mathrm{kg})\end{array}$ & $\begin{array}{c}\text { Measured } \\
\text { Decant \#9 } \\
(\mathrm{mg} / \mathrm{kg})\end{array}$ \\
\hline TIC & 840 & 835 & 900 & 1020 \\
\hline Nitrite & 8400 & 8300 & 2390 & 2130 \\
\hline Nitrate & 2570 & 2250 & 1570 & 1280 \\
\hline Sulfate & 860 & 804 & 920 & 848 \\
\hline Oxalate & 39,840 & 53,200 & 26,750 & 24,900 \\
\hline
\end{tabular}

Sodium hydroxide is present in the simulant. The common starter simulant was nearly free of sodium chloride, but did have small concentrations of sodium fluoride and sodium phosphate. The anion targets were obtained by matching an estimate of the supernate composition with an estimate of the insoluble solids composition for each wash endpoint. Anions were totaled and compared to the anions in the starter sludge. Additional species (sodium salts plus potassium nitrate) were added to bring the anions up to the estimated total values. Total sodium was allowed to float to whatever value was required to get the anions correct.

Physical property data were also obtained after the sludges were prepared. The data are summarized in Table 6-4.

Table 6-4. Additional Characterization Data for Decant \#5 and Decant \#9 Sludges.

\begin{tabular}{|l|c|c||}
\hline & Decant \#5 & Decant \#9 \\
\hline Wt. \% Total Solids & 19.1 & 18.1 \\
\hline Wt. \% Calcined Solids @ 900C & 13.3 & 13.3 \\
\hline Wt. \% Insoluble Solids & 15.2 & 15.0 \\
\hline Wt. \% Soluble Solids & 3.9 & 3.1 \\
\hline Base Equivalents, M at pH 7 & 0.385 & 0.439 \\
\hline Sludge pH & 11.3 & 11.2 \\
\hline Sludge Density, g/ml & 1.14 & 1.14 \\
\hline
\end{tabular}

The pattern of obtaining a lower wt. $\%$ calcined solids at $1100^{\circ} \mathrm{C}$ vs. $900^{\circ} \mathrm{C}$ has been seen throughout the work with sodium oxalate sludge simulants (Herman et al. 2002b; Herman et al. 2003). 


\subsection{Frit Fabrication}

Table 4-3 identified the targeted compositions of the nine frits prepared for this study. With the exceptions of Frits 202 and 320 which were fabricated by an outside vendor, each frit was prepared from the proper proportions of reagent-grade metal oxides, carbonates, and $\mathrm{H}_{3} \mathrm{BO}_{3}$ in 300-g batches using SRTC technical procedure "Glass Batching - ITS-0001" (SRTC 2002a). Batch sheets were filled out as the materials were weighed. Once batched, the frits were melted using SRTC technical procedure "Glass Melting - ITS-0003" (SRTC 2002b). In general, the raw materials were thoroughly mixed and placed into a 500-mL crucible. If the frit melted at $1200^{\circ} \mathrm{C}$ or below, a 95\% Platinum / 5\% Gold crucible was used. A 90\% Platinum / 10\% Rhodium crucible was used when the melt-temperature was greater than $1200^{\circ} \mathrm{C}$. Frits 411 and 416 melted at $1150^{\circ} \mathrm{C}$; Frit 405 at $1250^{\circ} \mathrm{C}$; Frits 421,422 , and 423 at $1300^{\circ} \mathrm{C}$; and Frit 409 at $1400^{\circ} \mathrm{C}$. The batch was subsequently placed into a high-temperature furnace (at pre-determined setpoint). After an isothermal hold at temperature for 1.0 hour, the crucible was removed, and the frit was poured onto a clean stainless steel plate and allowed to air cool. Observations of the resulting pour patty and residual crucible glass were documented. ${ }^{10}$

The pour patty and residual crucible glass were ground, and the crushed glass was subsequently transferred to its original $500-\mathrm{mL}$ crucible for a second melt at the determined melt temperature. After an isothermal hold at temperature for 1.0 hour, the crucible was removed, and the frit was again poured onto a clean stainless steel plate and allowed to air cool. Observations of the resulting pour patty and residual crucible glass were again documented. Approximately $280 \mathrm{~g}$ of glass was removed (poured) from the crucible while $\sim 20 \mathrm{~g}$ remained in the crucible along the walls. Each glass was ground and sieved to a particle size of $-80,+200$ mesh (consistent with the frit particle size currently used at DWPF). The $-80,+200$ mesh-sized material was then mixed with the simulated SB3 SRAT product (at the targeted WL) for each MRF test. To confirm the targeted frit compositions were met, representative samples of each $-80,+200$ mesh frit were obtained and submitted to the SRTC-ML for compositional analysis.

\subsection{SRAT Process}

Two 15-liter SRAT cycles were performed for each decant (\#5 and \#9) with simulated sludge to produce the amounts of SRAT product necessary for the planned dry-feed MRF tests. Run plans (Lorier 2002a; Lorier 2002b) specific for each decant outlined the specific SRAT steps that were consistent with procedures discussed by Stone and Lambert (2001). In general, each SRAT cycle consisted of adding coal and sand to the pretrimmed sludge (amounts specific for each decant), adding nitric acid and formic acid at $93^{\circ} \mathrm{C}$ to acidify the sludge (based on the acid addition strategy - see Section 5.0), concentrating the batch to the original volume, and then refluxing the batch at boiling for 12 hours. The nitric / formic acid ratio was specific for each decant and targeted a glass redox of $0.2 \mathrm{Fe}^{2+} / \Sigma \mathrm{Fe}$, according to the interim redox correlation (Jantzen, 2002). A sample of each batch of SRAT product was analyzed to determine the calcine factor (amount of solids remaining after the sample was heated to $900^{\circ} \mathrm{C}$ - see Table 6-4). The calcine factor (plus WL) was used to determine the amount of frit to add to produce the melter feed.

If the SRAT minimum $\mathrm{pH}$ (following the addition of the $110 \%$ acid) did not fall below 4.9 , then additional acid was to be added until this occurred. This decision was made based on runs with $50 \%$ oxalate in Tank 8 simulant where higher pH's correlated to incomplete nitrite destruction.

\footnotetext{
${ }^{10}$ Observations of homogeneity and $\mathrm{T}_{\mathrm{M}} \mathrm{S}$ were documented in WSRC-NB-2001-00059. No visual signs of undissolved solids or compositional inhomogeneities were observed.
} 
The nominal acid requirements and actual acid additions to the $16.65 \mathrm{~kg}$ batches were as defined in Table 6-5.

Table 6-5. Acid Targets for Decant \#5 and Decant \#9 Processing.

\begin{tabular}{||l|c|c|c||}
\hline \hline & $\begin{array}{c}\text { Decant \#5 } \\
\text { (Nominal \& Actual) }\end{array}$ & $\begin{array}{c}\text { Decant \#9 } \\
\text { (Nominal) }\end{array}$ & $\begin{array}{c}\text { Decant \#9 } \\
\text { (Actual) }\end{array}$ \\
\hline Nitric Acid & 6.55 moles & 5.58 moles & 6.35 moles \\
\hline Formic Acid & 13.68 moles & 10.59 moles & 11.98 moles \\
\hline \hline
\end{tabular}

During the initial Decant \#9 run, the $\mathrm{pH}$ did not fall below 4.9 during acid addition. Three further additions of both nitric acid and formic acid, representing $~ 13 \%$ additional acid, were made until a $\mathrm{pH}$ of $\sim 4.9$ was obtained. Later work showed that it was not necessary to reach a $\mathrm{pH}$ less than 4.9 to adequately destroy nitrite in the Decant \#9 recipe. The $13 \%$ additional acid was not absolutely necessary to prepare in-spec melter feed. Still, it appears that Decant \#9 SRAT product was prepared with at most $25 \%$ excess acid over that needed to bring the nitrite below $1000 \mathrm{ppm}$. It was more likely that the Decant \#9 excess acid was in the 15-20\% range. Later 4liter scale work with Decant \#5 showed that $100 \%$ acid by the above equation was about a $1-5 \%$ excess over the minimum acid required to ensure nitrite destruction. The $110 \%$ level acid addition used here was ultimately about $11-15 \%$ over the minimum required. Therefore, the Decant \#5 and Decant \#9 excess acid levels were roughly similar and in the 11-20\% range, i.e. in the $111-120 \%$ region of stoichiometry. Both cases were in the range of historical levels of excess acid. However, the assumption made was that the acid addition strategy chosen for each decant had the same effect on all frits tested.

\subsection{Melt Rate Tests}

This section describes a general overview of the MRF and standard procedures utilized while operating the MRF. The MRF installed in the high-bay of 999-1W was utilized to compare melt rate and melting behavior of different feed formulations for the DWPF. The MRF was designed to mimic the characteristics of heat transfer to the cold cap representative of a large-scale jouleheated melter. This is done by providing heating in one dimension through the bottom of a crucible and insulating the sides in the melt pool area to minimize radial heat transfer to or from the melt pool and heat exchange with the plenum. This mimics the heat flow that would be present in a large melter that relies on convective and conductive heat transfer between the glass pool and cold cap.

The furnace inner chamber is approximately one cubic foot with 1925-watt plate heaters mounted on the two side-walls (see Figure 6-1). The insulation consists of approximately 6" of M-board ${ }^{11}$ on all sides of the furnace chamber. The top board has a 6" circular cutout through all layers of insulation to hold a $1200-\mathrm{mL}$ stainless steel beaker and insulating sleeve in place. The tests were conducted with 6" deep stainless steel beakers inserted into the cutout so that the top flange of the beaker was just above the top of the furnace. The beaker bottom was approximately flush with

\footnotetext{
${ }^{11} \mathrm{M}$-board is a refractory ceramic fiber-board manufactured by Thermal Ceramics used for high-temperature insulation purposes.
} 
the top of the inner furnace chamber. An insulating block was used to cover the top of the beaker. The furnace had a setpoint of $1150^{\circ} \mathrm{C}$ with the top opening covered, but a maximum temperature of only $\sim 1130^{\circ} \mathrm{C}$ could be achieved $\left(20^{\circ} \mathrm{C}\right.$ below the nominal DWPF melt pool temperature). Once the furnace reached this temperature, the cover was removed and the beaker containing sufficient frit and SB3 SRAT product to produce $\sim 500$ grams of glass was inserted. With the $1130^{\circ} \mathrm{C}$ melt temperature coupled with the 42-minute residence time, it was expected that complete conversion of the feed materials into a single-phase glass product would not occur for each test.

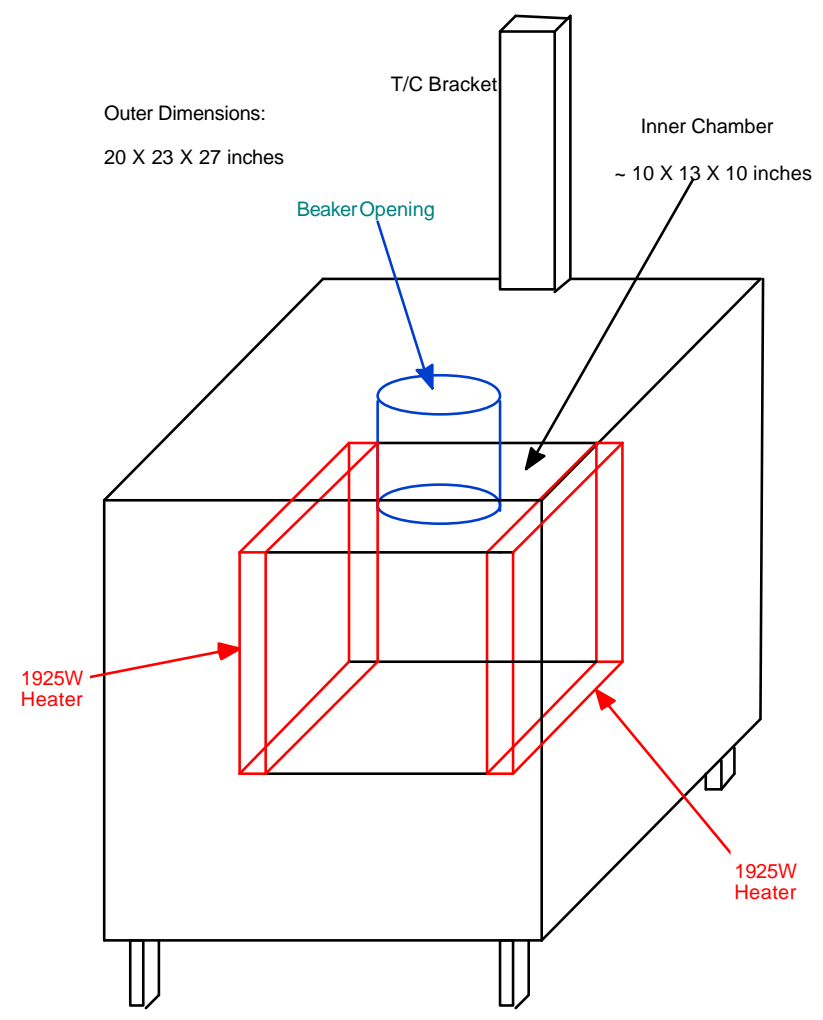

Figure 6-1. Schematic design of the MRF.

The temperature in each beaker was measured at four heights: 1/2", 1", 2", and 5" from the beaker bottom (see Figure 6-2). The furnace inner chamber temperature was also recorded. Once the beaker had been in the furnace for 42 minutes, it was removed from the furnace and allowed to air cool.

The method used to determine the linear melt rate was to measure the height of the glass pool formed during each test and divide by the run time (consistent with that used by Stone and Josephs (2001) and Lorier and McGrier (2002)). The beakers were sectioned in half and the height of the glass pool was measured from the bottom of the beaker to the point where the glass was no longer free of bubbles. Linear melt rate determinations involved measuring the glass height at $1 / 4$ " intervals across the beaker, and then averaging the values to obtain an average glass pool height. The average glass pool height was divided by the run time to obtain the melt rate result in inches per hour. 


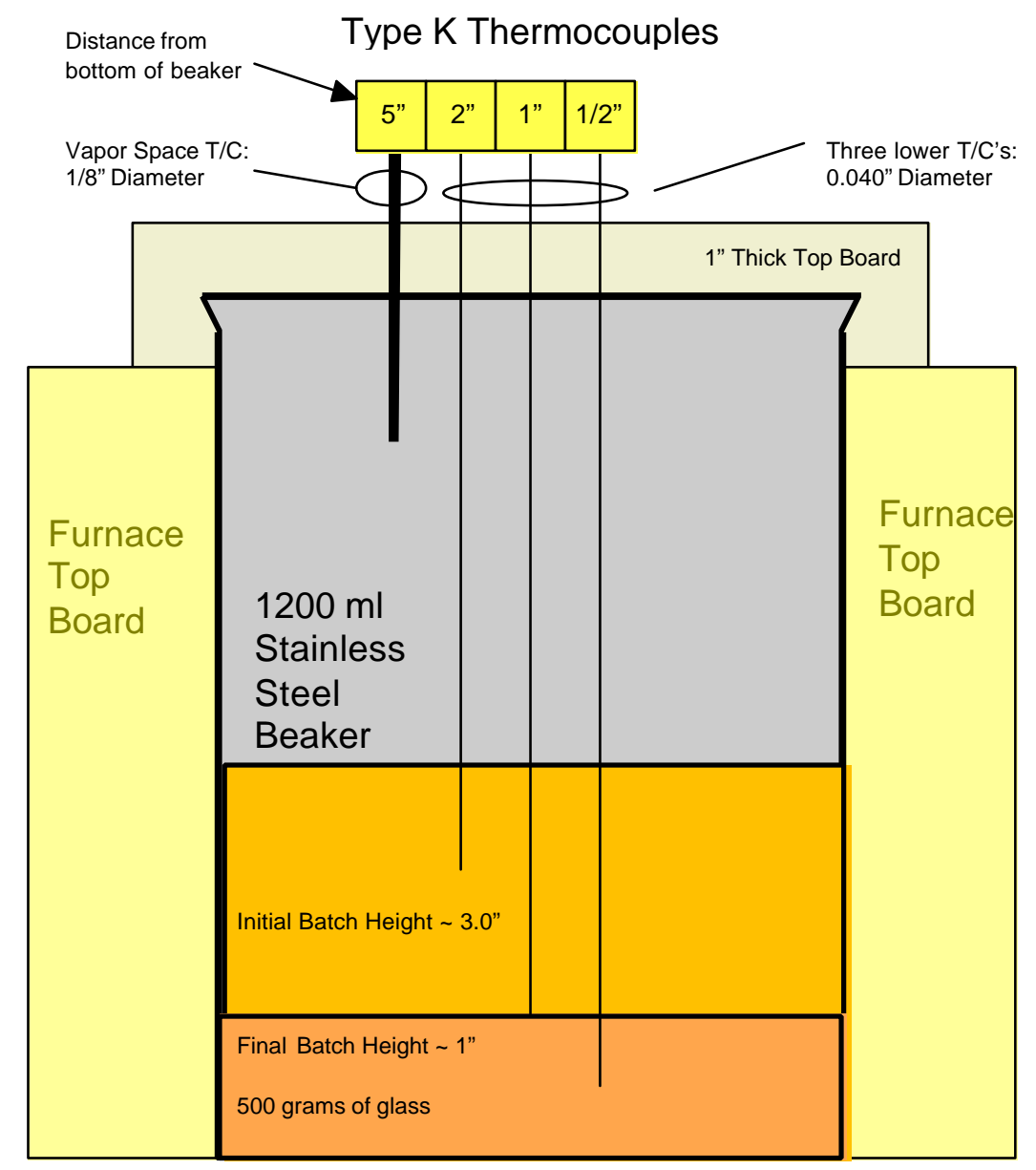

Figure 6-2. Schematic of beaker inserted into the MRF.

It should also be noted that the SB3 melt rate assessments are based solely on the dry-fed MRF results which induces some risks, although minimal, based on recent data linking the dry-fed system to slurry-fed melters. More specifically, the same procedures discussed in Stone and Josephs (2001) for the operation of the MRF and the setup of the beakers for the SB2 testing were followed for this SB3 testing. In the testing of SB2, it was shown that the same melt rate trends observed in the dry-fed MRF were demonstrated in the Slurry Fed Melt Rate Furnace (SMRF) and the Minimelter (Lorier et al. 2002; Miller 2002). This provides confidence that the MRF results will positively impact the frit down selection process. More specifically, the results should allow the SB3 frit development team to utilize the MRF results with a high probability of identifying frits that demonstrate the same melt rate trends in larger-scaled systems (up to the Minimelter). Therefore, the probability or risk of eliminating a candidate frit based on a poor performance in the MRF which would have performed well in a larger scale slurry based system is low based on historical data.

The selected frits were chosen based on the robustness of their operating window within each decant, the availability of the frit (Frits 202 and 320 already fabricated), and how similar one frit 
was to another (e.g., determined that it was not necessary to test both Frits 409 and 410). The frits chosen for testing were Frit 202, 320, 405, 409, 411, 416, 421, 422, and 423 (Table 4-3). Each frit and their specific tested waste loadings are listed in Table 6-6. Frit 405 was not tested with Decant \#9 due to only a 3\% WL operating window (32-34\%). Based on PCCS predictions, Frit 320 would not be acceptable with either decant unless the PCT constraints were ignored. However, as noted by Peeler and Edwards (2002), DWPF and HLW CP\&A personnel expressed interests in the use of Frit 320, even though model based predictions of unacceptability did exist. Rios-Armstrong (2002b) identified the need to evaluate systems that were classified as unacceptable. If the PCT constraint is ignored for the Frit 320 / Decant \#9 system, the acceptable WL operating window would be $28-34 \%$. Therefore, Frit 320 was tested with Decant \#9 at waste loadings of 30\% and 35\%. Also, Frit 409 was tested with Decant \#9 at WLs of $40 \%$ and $45 \%$ since PCCS predicted a small WL-operational window of $39-44 \%$.

Table 6-6. Frits Tested for SB3 (Decants \#5 and \#9) and Waste Loading Designation.

\begin{tabular}{||c|c|c||}
\hline & \multicolumn{2}{|c|}{ Tested Waste Loadings: } \\
\hline Frit & Decant \#5 & Decant \#9 \\
\hline 202 & $35 \%, 40 \%$ & $30 \%, 35 \%, 40 \%$ \\
\hline 320 & None & $30 \%, 35 \%$ \\
\hline 405 & $30 \%, 40 \%$ & None \\
\hline 409 & $30 \%, 35 \%$ & $40 \%, 45 \%$ \\
\hline 411 & $30 \%, 35 \%, 40 \%$ & $30 \%, 35 \%, 40 \%$ \\
\hline 416 & $30 \%, 35 \%, 40 \%$ & $30 \%, 35 \%, 40 \%$ \\
\hline 421 & $30 \%, 35 \%, 40 \%$ & $30 \%, 35 \%, 40 \%$ \\
\hline 422 & $30 \%, 35 \%, 40 \%$ & $30 \%, 35 \%, 40 \%$ \\
\hline 423 & $30 \%, 35 \%, 40 \%$ & $30 \%, 35 \%, 40 \%$ \\
\hline
\end{tabular}




\subsection{Results and Discussion}

This section provides a detailed discussion of the chemical composition measurements for the fabricated frits and of the melt rate assessments for the various frit / sludge combinations.

\subsection{Frit Fabrication}

To confirm that the "as-fabricated" frit compositions corresponded to the defined target compositions, representative samples (after grinding) were submitted to the SRTC-ML for chemical analysis. The results of the compositional analyses are shown in Table 7-1. Overall, comparisons between the measured and targeted compositions suggest that there were no significant problems in the batching or fabrication of the SB3 candidate frits. It is interesting to note that volatility was not a major issue associated with the production of the more refractory frits which required a higher melting temperature $\left(\mathrm{T}_{\mathrm{M}}\right.$; melt temperatures used to fabricate each frit also shown in Table 7-1). Although these frits were successfully melted in the laboratory, a more formal assessment should be made with respect to their potential fabrication by a vendor.

Table 7-1. Target Versus Measured Compositions (wt\%) for SB3 Candidate Frits.

\begin{tabular}{|c|c|c|c|c|c|c|c|c|c|c|}
\hline Oxide & \multicolumn{2}{|c|}{ Frit 202} & \multicolumn{2}{|c|}{ Frit 320} & \multicolumn{2}{|c|}{ Frit 405} & \multicolumn{2}{|c|}{ Frit 409} & \multicolumn{2}{|c|}{ Frit 411} \\
\hline & Target & Measured & Target & Measured & Target & Measured & Target & Measured & Target & Measured \\
\hline $\mathrm{Al}_{2} \mathrm{O}_{3}$ & - & 0.665 & - & 0.223 & - & 0.200 & - & 0.224 & 1 & 1.13 \\
\hline $\mathrm{B}_{2} \mathrm{O}_{3}$ & 8 & 7.99 & 8 & 9.18 & 20 & 20.005 & 8 & 8.026 & 8 & 8.15 \\
\hline $\mathrm{Li}_{2} \mathrm{O}$ & 7 & 6.76 & 8 & 8.45 & 5 & 4.902 & 4 & 3.962 & 5 & 4.94 \\
\hline $\mathrm{Na}_{2} \mathrm{O}$ & 6 & 6.00 & 12 & 10.4 & - & 0.000 & 6 & 5.839 & 12 & 12.13 \\
\hline $\mathrm{SiO}_{2}$ & 77 & 75.5 & 72 & 73.8 & 75 & 74.662 & 82 & 81.381 & 74 & 74.01 \\
\hline $\mathrm{MgO}$ & 2 & 2.06 & - & - & - & - & - & - & - & - \\
\hline \begin{tabular}{|l|} 
Total \\
\end{tabular} & 100 & 98.975 & 100 & 102.053 & 100 & 99.769 & 100 & 99.432 & 100 & 100.36 \\
\hline $\mathrm{T}_{\mathrm{M}}$ & \multicolumn{2}{|c|}{$\mathrm{NA}^{\text {(a) }}$} & \multicolumn{2}{|c|}{$\mathrm{NA}^{\text {(a) }}$} & \multicolumn{2}{|c|}{$1250^{\circ} \mathrm{C}$} & \multicolumn{2}{|c|}{$1400^{\circ} \mathrm{C}$} & \multicolumn{2}{|c|}{$1150^{\circ} \mathrm{C}$} \\
\hline
\end{tabular}

${ }^{\text {(a) }}$ Frit manufactured by an off-site vendor for DWPF.

\begin{tabular}{||c|c|c|c|c|c|c|c|c||}
\hline Oxide & \multicolumn{2}{|c|}{ Frit 416 } & \multicolumn{2}{c|}{ Frit 421 } & \multicolumn{2}{c|}{ Frit 422 } & \multicolumn{2}{c|}{ Frit 423 } \\
\hline & Target & Measured & Target & Measured & Target & Measured & Target & Measured \\
\hline $\mathrm{Al}_{2} \mathrm{O}_{3}$ & 1 & 1.13 & 1 & 1.17 & - & 0.267 & - & 0.191 \\
\hline $\mathrm{B}_{2} \mathrm{O}_{3}$ & 8 & 8.16 & 10 & 10.21 & 8 & 9.196 & 10 & 9.216 \\
\hline $\mathrm{Li}_{2} \mathrm{O}$ & 8 & 7.87 & 5 & 4.96 & 8 & 7.962 & 8 & 7.866 \\
\hline $\mathrm{Na}_{2} \mathrm{O}$ & 11 & 11.07 & 7 & 6.82 & 3 & 2.686 & 3 & 2.488 \\
\hline $\mathrm{SiO}_{2}$ & 72 & 70.97 & 77 & 76.05 & 81 & 78.254 & 79 & 78.538 \\
\hline $\mathrm{MgO}$ & - & - & - & - & - & - & - & - \\
\hline Total & 100 & 99.2 & 100 & 99.21 & 100 & 98.365 & 100 & 98.299 \\
\hline $\mathrm{T}_{\mathrm{M}}$ & \multicolumn{3}{|c|}{$1150^{\circ} \mathrm{C}$} & \multicolumn{3}{|c|}{$1300^{\circ} \mathrm{C}$} & \multicolumn{3}{c|}{$1300^{\circ} \mathrm{C}$} & \multicolumn{2}{c|}{$1300^{\circ} \mathrm{C}$} \\
\hline
\end{tabular}

(b) It is recognized that the measured $\mathrm{SiO}_{2}$ concentration was significantly lower than target. But considering Frit 422 is not a primary candidate for either Decant, this discrepancy is not pertinent. 


\subsection{Melt Rate Tests}

The objective of this task is to assess the influence of frit composition on the melt rate and melting behavior for two separate SB3 washing scenarios utilizing the dry-fed MRF. The results will aid in increasing our basic understanding of the role of glass chemistry on the overall melting process of SB3 ultimately leading to an assessment of the parameters that define optimal waste throughput which may be a compromise between waste loading and melt rate. Given the use of both Decant \#5 and Decant \#9, the results will also allow a secondary (but critical) assessment of the effect of washing on melt rate. In other words, the results may provide incentive to provide a less washed sludge (enhanced alkali concentration) to improve melt rate or waste throughput potential.

Prior to a detailed discussion of the melt rate assessments for each specific frit / decant system, general observations are reported that provide a high-level overview of the results. In the subsequent sections, 7.2.2 and 7.2.3, specific melt rate information for Decant \#5 and Decant \#9 are reported, respectively.

\subsubsection{General Observations}

Two general observations were made during the melt rate assessments for both Decant \#5 and Decant \#9. Although these observations are general in nature, they provide valuable insight into the usefulness of the MRF as a significant tool to assess melt rate and the potential SB3 integrated flowsheet. The first observation was the fact that after 42 minutes in the melt rate furnace, all systems contained some degree of unreacted material. Complete conversion of the SRAT / frit system into a single-phase glass would have been an indication of an extremely high batch-toglass conversion process or melt rate within the standard 42 minutes. The presence of the cold cap and unmelted material though provides the opportunity to assess not only melt rate, but melt behavior as well. Lorier et al. (2002) indicated that although melt rate was a primary parameter of interest, melt behavior was also a critical parameter that is directly linked to melt rate and ultimately waste throughput potential. In terms of melt behavior, one specifically uses the cold cap and its structure to assess the foam potential of a system, which is linked to melt rate and ultimately defines waste throughput potential. Structural characteristics of interest include the void volume and/or size, the height of the cold cap, the interface between the cold cap and the molten glass pool, and the degree or amount of unreacted material. Although melt rate was measured and will be reported, the frit down-select process also accounted for the melt behavior or cold cap characteristics. Again, the presence of a cold cap in all systems allows for both a formal measurement of melt rate as well as an assessment of melt behavior - both critical inputs to maximize waste throughput potential.

The second general observation was the lack of $\mathrm{a} \mathrm{SO}_{3}$ or salt layer formation (or deposits) within the cold cap or along the MRF crucible walls for any of the systems evaluated. The lack of this formation provides insight into the ability of these systems to tolerate the targeted $\mathrm{SO}_{3}$ concentrations in glass. Peeler and Edwards (2002) identified the potential of $\mathrm{SO}_{3}$ formation or of exceeding solubility limits as an outstanding issue inlight of the relatively high WLs that were projected based on model predictions coupled with the potential use of a less washed sludge. Although $\mathrm{SO}_{3}$ was not observed in any of the melt rate tests, this issue should continue to be monitored or assessed as the SB3 flowsheet evolves and matures. In fact, $\mathrm{SO}_{3}$ partitioning may differ when slurry feeding is utilized. 


\subsubsection{Decant \#5-Based Systems}

Table 7-2 provides the linear melt rate data as a function of WL for the various Decant \#5-based systems. Also included in Table 7-2 are the projected operational windows for each system resulting from the model-based assessments. The following sections discuss the results of the MRF tests based on a frit classification system in terms of refractoriness (or ease of melting). The eight frits listed in Table 7-2 were placed into one of two categories: (1) refractory $\left(\mathrm{T}_{\mathrm{M}} \geq\right.$ $\left.1250^{\circ} \mathrm{C}\right)$ or $(2)$ high alkali $\left(\mathrm{T}_{\mathrm{M}}<1250^{\circ} \mathrm{C}\right)$. It is recognized that the classifications are somewhat ill-defined from a technical standpoint but do provide a platform from which the effect of frit composition on melt rate can be easily discussed. Table 7-1 lists the $\mathrm{T}_{\mathrm{M}} \mathrm{S}$ used to fabricate each frit. Given Frit 320 and Frit 202 were fabricated by an off-site vendor, they were considered high alkali and refractory frits, respectively.

\subsubsection{Decant \#5: Refractory Frits}

Based on $\mathrm{T}_{\mathrm{M}} \mathrm{s}$, the refractory frits include: Frit 405, Frit 409, Frit 421, Frit 422, Frit 423, and Frit 202. The relatively high $\mathrm{SiO}_{2}$ and low alkali contents of these frits were the primary reasons those high fabrication temperatures were required. In general, the more refractory frits provide relatively large operational windows when coupled with Decant \#5. As previously mentioned, this is based on the need to compositionally compensate the high alkali sludge with a low alkali based frit in order to obtain an overall balanced glass system. Frit 405 and Frit 409 show the highest tolerance to anticipated composition variation with $100 \%$ of all EVs capable of being processed. With respect to the melt rate assessments, at $30 \% \mathrm{WL}$, a significant difference is observed in measured linear melt rate between these two systems. The melt rate for the Frit 405 based system is $0.73 \mathrm{in} / \mathrm{hr}$ compared to $0.92 \mathrm{in} / \mathrm{hr}$ for the Frit 409 based system. Although the $\mathrm{SiO}_{2}$ concentration is higher for Frit 409, the higher alkali content in Frit 409 presumably leads to the enhanced melt rate relative to Frit 405 . The high $\mathrm{B}_{2} \mathrm{O}_{3}$ content of Frit 405 does not appear to enhance melt rate, which is consistent with the observations by Peeler et al. (2001) during melt rate assessments for SB2. As WL is increased to $40 \%$ in the Frit 405 system, melt rate slightly decreases (a 35\% WL test not performed). This trend is consistent with the Frit 320 / SB2 systems as defined by Lorier and McGrier (2001). In the Frit 409 system, melt rate does not appear to diminish at $35 \% \mathrm{WL}$. Given the lack of SRAT product, a test at $40 \% \mathrm{WL}$ was not performed but is recommended if Frit 409 remains a primary frit candidate for Decant \#5. It should be noted that given the compositional similarity between Frit 409 and Frit 410, it is anticipated that the linear melt rates for the Frit 410 / Decant \#5 system would mirror those of the Frit 409-based systems as a function of WL.

The projected operational windows for the Frit 421, Frit 422, Frit 423, and Frit 202 based systems are not as robust as Frit 405 or Frit 409, but have extremely large WL intervals when the nominal Decant \#5 composition is considered. The Frit 202 / Decant \#5 based system has the smallest projected operational window (33 - 39\% based on the nominal sludge composition) of the "refractory" frits - thus no assessment of melt rate was performed at 30\% WL. Although a smaller, less robust window exists for the Frit 202 system, it yielded one of the highest measured linear melt rates $(1.04 \mathrm{in} / \mathrm{hr})$ at $35 \% \mathrm{WL}$ (indistinguishable from the $1.05 \mathrm{in} / \mathrm{hr}$ in the Frit 423 system at 30\% WL). More importantly, as WL increases in the Frit 202 system to $40 \% \mathrm{WL}$, the impact on melt rate was negligible $(1.04 \mathrm{in} / \mathrm{hr}$ to $1.00 \mathrm{in} / \mathrm{hr})$. The projected small operational window, however, and the inability of the system to handle compositional variation to a high degree (based on model predictions) may offset the potential advantage of utilizing Frit 202 with 
Decant \#5. The need to balance conflicting goals such as these will weigh heavily on the SB3 frit development team as all the information is assimilated and processed during the final frit selection process leading to a recommendation for SB3.

The projected operational windows for Frit 421, Frit 422, and Frit 423 are essentially identical. However, the measured linear melt rate for and the melt rate response to WL changes differ quite dramatically. Consider the Frit 423 based system. At 30\% WL, this system had the highest measured linear melt rate of all the Decant \#5 systems evaluated. As WL was increased, the melt rate response as measured in the MRF was less than ideal. Melt rate continually diminishes with increased WL. Although this same effect was observed with the Frit 320 / SB2 system, Lorier and McGrier (2002) indicated that this trend should be viewed cautiously as the primary measure should be focused on total waste throughput (see Section 7.2.2.4 for more details).

For the Frit 422 based glasses, the measured linear melt rate was essentially constant as a function of WL. Although the insensitivity of melt rate to WL is usually advantageous, the relatively low measured melt rates are of concern. Once again, an assessment of the total waste throughput potential for this system is required.

One of the more promising systems evaluated for Decant \#5 was based on Frit 421. The measured linear melt rates were all quite high and essentially remained flat as a function of WL. This frit should be considered as a primary candidate even though its response to compositional variation is less than ideal.

Table 7-2. Decant \#5 Linear Melt Rate Data

\begin{tabular}{||l|c|c|c|c|c|c|c|c||}
\hline & $\begin{array}{c}\text { Frit } \\
405\end{array}$ & $\begin{array}{c}\text { Frit } \\
409\end{array}$ & $\begin{array}{c}\text { Frit } \\
421\end{array}$ & $\begin{array}{c}\text { Frit } \\
422\end{array}$ & $\begin{array}{c}\text { Frit } \\
423\end{array}$ & $\begin{array}{c}\text { Frit } \\
202\end{array}$ & $\begin{array}{c}\text { Frit } \\
416\end{array}$ & $\begin{array}{c}\text { Frit } \\
411\end{array}$ \\
\hline WL (nom) & $31-46$ & $33-50$ & $30-44$ & $31-46$ & $31-44$ & $33-39$ & None & None \\
\hline WL all EVs & $36-39$ & $36-41$ & $34-35$ & $36-39$ & $36-37$ & None & --- & --- \\
\hline WLV E some WL & $100 \%$ & $100 \%$ & $100 \%$ & $100 \%$ & $100 \%$ & $70 \%$ & --- & --- \\
\hline Min. WL & $100 \%$ & $100 \%$ & $87.8 \%$ & $95.7 \%$ & $90.2 \%$ & $51.6 \%$ & --- & --- \\
\hline Linear MR (30\% WL) & $9 \%$ & $6 \%$ & --- & --- & --- & --- & --- & --- \\
\hline Linear MR (35\% WL) & NM & 0.91 & 0.99 & 0.71 & 0.81 & 1.04 & 0.88 & 0.67 \\
\hline Linear MR (40\% WL) & 0.66 & NM & 0.94 & 0.70 & 0.73 & 1.00 & 0.69 & 0.63 \\
\hline
\end{tabular}

Note: Generally frits become less refractory moving left to right.

\subsubsection{Decant \#5: High Alkali Frits}

Based on the $T_{M}$ classification, frits categorized as "high alkali" include: Frit 320, Frit 411, and Frit 416. Frit 320 was not assessed for Decant \#5 and as a result is not shown in Table 7-2. The high alkali content and relatively low $\mathrm{SiO}_{2}$ concentration make these frits much easier to melt (e.g., $\mathrm{T}_{\mathrm{M}}<1250^{\circ} \mathrm{C}$ ). It should be noted that these frits would be unacceptable in DWPF when coupled with Decant \#5. This latter statement reflects the fact that model predictions failed to identify a WL interval over which these frits could be used for Decant \#5 - even for the nominal sludge compositions. The relatively high alkali concentrations in both the frit and sludge lead to predictions that challenge the durability constraint over the entire WL range of interest. In terms of linear melt rates, there is a significant difference between Frit 416 and Frit 411 at 30 and 35\% 
WL - Frit 416 had the higher melt rate at both WLs. This difference can be explained by compositional differences in the frits - more specifically, the trend between total alkali content and melt rate as observed by Stone et al. (2001). Frit 416 has a targeted alkali concentration of $19 \%$ while Frit 411 has an alkali content of $17 \%$. It appears that this $2 \%$ difference in alkali concentration has a significant impact on linear melt rate. It should be noted that although these two frits have the highest alkali concentrations of all the Decant \#5 candidate frits, the measured linear melt rates are not the highest. In fact, the melt rate for Frit 411 is one of the lowest measured for this decant. This compositional trend challenges the highly correlated relationship observed by Stone et al. (2001) and implies that there is a more fundamental mechanism that is controlling melt rate for the Decant \#5 systems. Given the uncertainties associated with the acid addition strategy for SB3 (see Section 5.0), one can not rule out the possibility that the acid addition strategy and/or the presence of oxalate or coal in SB3 may bias this compositional trend. However, it is assumed that the acid addition strategy had little or no impact on the relative melt rate assessment for both Decant \#5 and Decant \#9.

\subsubsection{Potential Impacts to DWPF}

Melt rate became a concern for DWPF as the SB2 / Frit 200 system was being processed. This prompted the development (Peeler et al. 2001; Stone and Josephs 2001) and recommendation (Lambert et al. 2001) of Frit 320 to improve melt rate for SB2. Linear melt rates as a function of WL were measured for the Frit 320 / SB2 system (Lorier and McGrier, 2002) and are summarized in Table 7-3. The linear melt rate for the Frit 200 / SB2 system at 25\% WL was 0.77 in/hr. Utilizing the MRF and SMRF, Lorier et al. (2002) reported that Frit 320 melts faster ( 20 $-30 \%$ ) than Frit 200 at 25\% WL for SB2. This was confirmed by Miller et al. (2002) in the Minimelter.

Given the use of a constant 42-minute exposure time in the MRF for both SB2 and SB3 tests, melt rate comparisons can be made with respect to potential SB3 processing issues in DWPF. More specifically, it is assumed that the results of the MRF and SMRF are directly translatable to DWPF and that the $0.77 \mathrm{in} / \mathrm{hr}$ is a baseline melt rate that is known to have issues in terms of DWPF processing. It should be noted that the 0.77 baseline is relevant solely to $25 \% \mathrm{WL}$ and comparisons at different WLs should be made with caution given the potential dependence of melt rate and WL. Given Frit 320 has not been processed in DWPF as of yet, it is also assumed that the measured melt rate of $1.04 \mathrm{in} / \mathrm{hr}$ at $25 \% \mathrm{WL}$ will be acceptable in terms of DWPF throughput.

Table 7-4 compares the linear melt rates for various frit / SB3 systems and the Frit 320 / SB2 system at 30, 35, and 40\% WL. ${ }^{12}$ In general, the measured melt rates for the SB3 systems have similar melt rates as those measured for the Frit 320 / SB2 system. This could be a positive indication that the formation of the "interface" layer has been minimized (or characteristics changed) - particularly at the lower WLs. It is only with Frit 423 at $40 \%$ WL that the measured rate drops below that of the Frit 200 / SB2 baseline rate of $0.77 \mathrm{in} / \mathrm{hr}$, which is considered to be "unacceptable".

\footnotetext{
${ }^{12}$ The linear melt rate values reported in Table 7-4 for the Frit 320 / SB2 systems at 30\% and 40\% WL are the averages of the $29-31 \%$ and $39-41 \%$ WL melt rate measurements.
} 
Table 7-3. Linear Melt Rate as a Function of WL for the Frit 320 / SB2 System.

[from Lorier and McGrier (2002)]

\begin{tabular}{||c|c||}
\hline WL & Linear melt rate (in/hr) \\
\hline 25 & 1.04 \\
\hline 27 & 1.04 \\
\hline 29 & 0.92 \\
\hline 31 & 0.93 \\
\hline 33 & 0.83 \\
\hline 35 & 0.87 \\
\hline 38 & 0.82 \\
\hline 38 & 0.69 \\
\hline 39 & 0.56 \\
\hline 41 & 0.58 \\
\hline
\end{tabular}

Table 7-4. Linear Melt Rates for Various Frit / SB Systems as a Function of WL.

\begin{tabular}{||c|c|c|c|c|c||}
\cline { 2 - 6 } \multicolumn{1}{c|}{} & SB2 & \multicolumn{4}{c|}{ SB3 (Decant \#5) } \\
\cline { 2 - 6 } \multicolumn{1}{c|}{} & Frit 320 & Frit 409 & Frit 421 & Frit 423 & Frit 202 \\
\hline \hline Linear MR (30\% WL) & 0.93 & 0.92 & 0.98 & 1.05 & NM \\
\hline Linear MR (35\% WL) & 0.87 & 0.91 & 0.99 & 0.81 & 1.04 \\
\hline Linear MR (40\% WL) & 0.57 & NM & 0.94 & 0.73 & 1.00 \\
\hline \hline
\end{tabular}

\subsubsection{Summary of Decant \#5 Melt Rate Assessment: Frit Down-Select Based on MRF Data}

The following is a summary of the major results of the Decant \#5 melt rate tests. The observations listed assume that the acid addition strategy had a minimal (or at least a constant) effect on the melt rate assessments. These observations ultimately were used in the down-select process that identified four primary frit candidates for Decant \#5. Also included in this section is an assessment of waste throughput for each of the primary systems.

$>$ A discernable difference in melt rate appears to exist as a function of frit composition.

$>$ The "high alkali" content frits (Frits 411 and 416) did not show marked improvement in melt rate. Although these glasses would not be processable in DWPF based on model predictions, based on previous compositional trends, it was expected that the melt rates for these high alkali systems would be higher than the frits with lower alkali content. Given the uncertainties associated with the acid addition strategy for SB3, one can not rule out the possibility that the acid addition strategy and/or the presence of oxalate or coal in SB3 may bias this compositional trend.

$>$ Frit 405 and Frit 409 show the highest tolerance to anticipated composition variation with $100 \%$ of all EVs capable of being processed. At $30 \% \mathrm{WL}$, a significant difference is 
observed in measured linear melt rate between these two systems. The higher alkali concentration in Frit 409 is presumably the basis for the higher melt rate. The relatively low melt rate associated with Frit 405 all but eliminates this frit from further consideration.

$>$ Frit 422 is robust to compositional variations, but it also exhibited low melt rates. Frits 202 and 421 had high melt rates, which remained almost "constant" as a function of WL. Frit 202 , however, has a small operational window and a lower tolerance to compositional variation.

$>$ Finally, Frit 423 showed a high melt rate at $30 \% \mathrm{WL}$, but its melt rate decreased as WL was increased (a similar trend was observed with the Frit 320 / SB2 system).

Based on these analyses, the list of candidate frits for SB3 Decant \#5 was narrowed to Frits 202, 409,421 , and 423. Waste throughput values for these four frits were calculated via Equation 1 (from Lorier and McGrier, 2002). The waste throughput values and melt rate observations for these frits are listed in Table 7-5.

$$
\text { Throughput } t_{W \amalg \# 2}=170\left(\frac{L M R_{W L \# 2}}{L M R_{30 \% W L}}\right)(W L \# 2)
$$

The waste loading of interest is WL\#2, Throughput ${ }_{\mathrm{WL} 2}$ is the waste throughput at that specified waste loading, and LMR is the linear melt rate. Note that the throughput values to be calculated will be based on the maximum linear melt rate at $30 \% \mathrm{WL}$. This calculation also assumes the amount of waste glass processed per hour by the DWPF is approximately 170 pounds.

Table 7-5. Waste Throughput and Melt Rate Observations for Decant \#5 Candidate Frits.

\begin{tabular}{|c|c|c|}
\hline \multicolumn{3}{|l|}{ Frit 202} \\
\hline WL & Throughput (lb/hr) & Comments \\
\hline $30 \%$ & --- & \multirow{3}{*}{$\begin{array}{ll}\text { - } & \text { high void volume } \\
\text { - } & \text { small window }\end{array}$} \\
\hline $35 \%$ & 58.93 & \\
\hline $40 \%$ & 64.76 & \\
\hline \multicolumn{3}{|l|}{ Frit 409} \\
\hline WL & Throughput (lb/hr) & Comments \\
\hline $30 \%$ & 44.69 & \multirow{3}{*}{$\begin{array}{ll}- & \text { high void volume } \\
\text { - } & \text { large window }\end{array}$} \\
\hline $35 \%$ & 51.57 & \\
\hline $40 \%$ & --- & \\
\hline \multicolumn{3}{|l|}{ Frit 421} \\
\hline WL & Throughput (lb/hr) & Comments \\
\hline $30 \%$ & 47.60 & \multirow{3}{*}{$\begin{array}{ll}- & \text { low void volume } \\
- & \text { medium window } \\
- & \text { throughput increases as WL } \\
& \text { increases }\end{array}$} \\
\hline $35 \%$ & 56.10 & \\
\hline $40 \%$ & 60.88 & \\
\hline \multicolumn{3}{|l|}{ Frit 423} \\
\hline$\overline{\mathrm{WL}}$ & Throughput (lb/hr) & Comments \\
\hline $30 \%$ & 51.00 (Baseline) & \multirow{3}{*}{$\begin{array}{ll}- & \text { high void volume } \\
- & \text { medium window } \\
- & \text { MR decreases as WL increases }\end{array}$} \\
\hline $35 \%$ & 45.90 & \\
\hline $40 \%$ & 47.28 & \\
\hline
\end{tabular}


The highest linear melt rate (1.05 in/hr) was based on the Frit 423, Decant \#5 system at 30\% WL. This system was used to establish a baseline from which an increase or decrease in waste throughput potential was compared. Using equation (1), the baseline waste throughput value is $51 \mathrm{lb} / \mathrm{hr}$. Values exceeding this baseline indicate an increase in total waste throughput potential; while values less than $51 \mathrm{lb} / \mathrm{hr}$ indicate a decreased waste throughput. Consider the waste throughput potentials for Frit 202 given its classification as a baseline frit by Elder (2002). Both throughput values at 35\% and 40\% (58.93 and $64.76 \mathrm{lb} / \mathrm{hr}$, respectively) exceed the baseline value of $51 \mathrm{lb} / \mathrm{hr}$ indicating that targeting the higher WLs for this system appears to be advantageous. The issue with this system still remains the relatively small operational window as defined by model predictions.

The Frit 409 system at 35\% WL yields approximately the same waste throughput potential as the baseline system (Frit 423 at 30\% WL). However, lower WLs appear to reduce the total waste throughput potential for this system. Given the lack of SRAT product, melt rate tests at $40 \% \mathrm{WL}$ were not performed but should be if Frit 409 continues to be a primary candidate. The primary outstanding issue with this frit is the potential for a vendor to fabricate this frit given the high $T_{M}$ $\left(1400^{\circ} \mathrm{C}\right.$, see Table $\left.7-1\right)$.

The Frit 421 based system is extremely interesting. The linear melt rates were essentially unaffected by increases in WL. Therefore, one would anticipate that the total waste throughput values for this system would continually increase with WL. This is reflected in Table 7-5 as the throughput values for $30 \%, 35 \%$, and $40 \%$ are $47.60,56.10$, and $60.88 \mathrm{lb} / \mathrm{hr}$, respectively. Based on these data, targeting a higher WL in this system may be advantageous from a waste throughput perspective relative to the baseline system.

For the Frit 423 system, total waste throughput decreases with increased waste loading. This is a result of the diminishing linear melt rate determinations as WL increased. Although the melt rates do decrease as WL increases in this system, the throughput values appear to go through a minimum value at $35 \% \mathrm{WL}$. Although a minimum is observed, the throughput values are relatively constant, which is a result of WL increases countering the diminishing melt rate.

\subsubsection{Decant \#9-Based Systems}

Table 7-6 provides the linear melt rate data as a function of WL for the various Decant \#9 based systems. Also included in Table 7-6 is the projected operational windows for each system resulting from the model-based assessments. The most notable aspects of the model-based assessments are that 6 of the 8 frits provide relatively large operational windows and demonstrate a high degree of robustness to anticipated compositional variation.

The following sections discuss the result of the MRF tests based on a frit classification system in terms of refractoriness (or ease of melting). The eight frits listed in Table 7-6 were placed into one of two categories: (1) refractory $\left(\mathrm{T}_{\mathrm{M}} \geq 1250^{\circ} \mathrm{C}\right)$ or (2) high alkali $\left(\mathrm{T}_{\mathrm{M}}<1250^{\circ} \mathrm{C}\right)$. It is recognized that the classifications are somewhat ill-defined from a technical standpoint but do provide a platform from which the effect of frit composition on melt rate can be easily discussed. Table 7-1 lists the $\mathrm{T}_{\mathrm{M}} \mathrm{S}$ used to fabricate each frit. Given Frit 320 and Frit 202 were fabricated by an off-site vendor, they were considered high alkali and refractory frits, respectively. 
Prior to a detailed review of the data, one observation is the fact that the measured linear melt rates for Decant \#9 are not as high as for the Decant \#5-based systems. The highest rate measured was $0.88 \mathrm{in} / \mathrm{hr}$ (Frit 320 at 35\% WL and Frit 423 at 35\% WL) compared to $1.05 \mathrm{in} / \mathrm{hr}$ for the Frit 423 / Decant \#5 system at 30\% WL. This may provide incentive for utilizing a less washed sludge for SB3.

Table 7-6. Decant \#9 Linear Melt Rate Data

\begin{tabular}{||l|c|c|c|c|c|c|c|c||}
\hline & Frit & Frit & Frit & Frit & Frit & Frit & Frit & Frit \\
$409^{(a)}$ & 421 & 422 & 423 & 202 & 411 & 416 & 320 \\
\hline WL (nominal) & $39-44$ & $30-45$ & $30-45$ & $28-45$ & $29-44$ & $26-46$ & $26-38$ & None \\
\hline WL all EVs & None & $34-37$ & $33-37$ & $32-37$ & $33-36$ & $30-38$ & None & None \\
\hline$\%$ EVs some WL & $100 \%$ & $100 \%$ & $100 \%$ & $100 \%$ & $100 \%$ & $100 \%$ & 58.5 & 66.1 \\
\hline WL of 5\% & $100 \%$ & $100 \%$ & $100 \%$ & $100 \%$ & $100 \%$ & $100 \%$ & 54.0 & 50.0 \\
\hline Min. WL & $9 \%$ & $6 \%$ & $6 \%$ & $10 \%$ & $9 \%$ & $9 \%$ & --- & --- \\
\hline Linear MR (30\% WL) & --- & 0.72 & 0.74 & 0.85 & 0.68 & 0.86 & 0.77 & 0.83 \\
\hline Linear MR (35\% WL) & --- & 0.69 & 0.75 & 0.88 & 0.81 & 0.79 & 0.65 & 0.88 \\
\hline Linear MR (40\% WL) & 0.72 & 0.54 & 0.69 & 0.68 & 0.56 & 0.74 & 0.63 & 0.68 \\
\hline
\end{tabular}

${ }^{\text {(a) }}$ Frit 409 was also tested at $45 \%$ WL with Decant \#9. The linear melt rate was $0.56 \mathrm{in} / \mathrm{hr}$.

\subsubsection{Decant \#9: Refractory Frits}

Based on $\mathrm{T}_{\mathrm{M}} \mathrm{s}$, the refractory frits include: Frit 409, Frit 421, Frit 422, Frit 423, and Frit 202. The relatively high $\mathrm{SiO}_{2}$ and low alkali contents of these frits are the primary reason those high fabrication temperatures were required.

First consider the measured linear melt rates as a function of WL for the Frit 202 system. At $30 \%$ $\mathrm{WL}$, the melt rate was measured to be $0.68 \mathrm{in} / \mathrm{hr}$ but improved dramatically at $35 \%$ WL $(0.81$ $\mathrm{in} / \mathrm{hr}$ ). At $40 \% \mathrm{WL}$, the melt rate drastically drops to $0.56 \mathrm{in} / \mathrm{hr}$. However, if the trend in melt rate is real, then targeting an intermediate WL may be advantageous. An assessment of total waste throughput will provide more insight into this effect (see Section 7.2.3.3).

The nominal WL range for Frit 409 with Decant \#9 is 39-44\% (Figure 7-6), so the tested waste loadings were $40 \%$ and $45 \%$. The linear melt rates were 0.72 and $0.56 \mathrm{in} / \mathrm{hr}$ for $40 \%$ and $45 \%$ WL, respectively. The linear melt rate for Frit 409 at $40 \%$ WL is greater than the other refractory frits with Decant \#9, but Frit 409 cannot be utilized at any waste loading less than $40 \%$ (no operating window and no melt rate assessment).

Frit 421 and Frit 422 show essentially the same trend in melt rate with WL. As WL is initially increased from $30 \%$ to $35 \%$, there appears to be little impact on melt rate. However, at $40 \%$ WL melt rate appears to diminish. Again, this trend is consistent with that observed by Lorier et al. (2001) for the Frit 320 / SB2 system.

Based on melt rate assessments alone, Frit 423 appears to be the primary candidate for Decant \#9 from the more refractory frits. Linear melt rates for this system remain relatively constant at $30 \%$ and $35 \% \mathrm{WL}(0.85$ and $0.88 \mathrm{in} / \mathrm{hr}$, respectively). Coupling the fact that this system has two of the 
highest measured melt rates and an extremely large projected operational window, this frit should be considered as a primary candidate for Decant \#9.

\subsubsection{Decant \#9: High Alkali Frits}

Based on the $T_{M}$ classification, frits categorized as "high alkali" for Decant \#9 include: Frit 320, Frit 411, and Frit 416. The high alkali content and relatively low $\mathrm{SiO}_{2}$ concentration make these frits much easier to melt (e.g., $\mathrm{T}_{\mathrm{M}}<1250^{\circ} \mathrm{C}$ ). It should be noted that Frit 320 would be prohibited in DWPF when coupled with Decant \#9. This latter statement reflects the fact that model predictions failed to identify a WL interval over which Frit 320 could be used for Decant \#9 - even for the nominal sludge compositions. The relatively high alkali concentrations in both the frit and sludge lead to predictions that challenge the durability constraint over the entire WL range of interest. Of the three "high alkali" frits, Frit 320 would have been a primary candidate. This latter statement is based on the fact that melt rate essentially remained constant from $30 \%$ to $35 \%$ WL. However, it cannot (and should not at this time) be considered the primary candidate for Decant \#9 based on model predictions.

The trends in linear melt rates for Frit 411 and Frit 416 as a function of WL are similar. As WL increases, melt rate decreases. Frit 411 would have a slight, although perhaps non-practical, advantage given its higher melt rate at each WL relative to Frit 416 . It should be mentioned that this trend is completely opposed to that observed in the Decant \#5 system for these two frits. The higher melt rates associated with Frit 416 in the Decant \#5 system were explained by the higher total alkali content in the frit. This reversal in melt rate trends challenges the highly correlated relationship observed by Stone and Josephs (2001) and implies that there is a more fundamental mechanism controlling melt rate for the Decant \#9 systems. Given the uncertainties associated with the acid addition strategy for SB3 (see Section 5.0), one can not rule out the possibility that the acid addition strategy and/or the presence of oxalate or coal in SB3 may bias this

compositional trend. In fact, it is assumed that the acid addition strategy had the same impact on the melt rate assessment of each frit for both Decant \#5 and Decant \#9.

A major concern for the Decant \#9 system is the absence of a "major" melt rate change as a function of frit composition. More specifically, there is no clear primary frit candidate(s) for this system based solely on melt rate. With the large compositional changes in frit, the assumption that the acid addition strategy had the same impact on each frit's assessments needs to be reconsidered or addressed. One would have expected a significant difference in melt rate given the large variation in frit composition targets.

\subsubsection{Summary of Decant \#9 Melt Rate Assessment: Frit Down-Select Based on MRF Data}

The following is a summary of the major observations from the Decant \#9 melt rate tests. The observations listed assume that the acid addition strategy had a minimal (or at least constant) effect on the melt rate assessments. These observations lead to the down-select of four primary frit candidates for Decant \#9. Also included in this section is an assessment of waste throughput for each of the primary systems.

$>$ A minimal impact of frit composition on melt rate was evident for the Decant \#9-based systems.

$>$ Relative to Decant \#5, the melt rates of Decant \#9 were lower. For example, Frit 202 with Decant \#5 had melt rates of 1.04 and 1.0 inches/hour at 35\% and 40\% WL, respectively. 
With Decant \#9 at 35\% and 40\% WL, the melt rates of Frit 202 were 0.81 and 0.56 inches/hour, respectively.

Given the non-differentiating assessments of melt rate for Decant \#9, evaluations of the melting behavior and foam potential played a significant role in the frit down-select process. The cold cap associated with the Frit 421 systems (all WLs) had high void volumes, which is an indication of foaming potential. For this reason, Frit 421 was not selected as a primary candidate. Frit 320 and Frit 416 were not selected primarily based on model predictions. Frit 320 would be prohibited from DWPF use with Decant \#9. Although an operating window does exist for Frit 416 , the robustness of this frit to compositional uncertainty is less than perfect. Coupling the low tolerance to compositional changes and a relatively low melt rate (due to the large batch expansion and void volumes), Frit 416 is not a primary frit for Decant \#9. The cold cap for Frit 409 was characterized by a large quantity of unreacted material indicating poor heat transfer to the upper batch. Based on this observation and the potential frit fabrication issues $\left(\mathrm{T}_{\mathrm{M}}=\right.$ $1400^{\circ} \mathrm{C}$ ), this frit was also removed from the primary frit candidate list for Decant \#9.

Frit 202, Frit 411, Frit 422, and Frit 423 continue to be considered as primary frits for Decant \#9. Cold caps resulting from Frits 202, 422, and 423 had relatively low void volumes translating to higher melt rates. Coupling the higher melt rates with the large operating windows was the primary driver for these frits being considered as primary candidates. Although large voids in the Frit 411 cold cap did exist, the relatively high melt rates provide incentive to maintain this frit on the list for further consideration.

The waste throughput values and melt rate observations for these frits are listed in Table 7-7. To assess the impact of WL on melt rate and throughput potential, a base case was established using the system with the highest melt rate at $30 \% \mathrm{WL}$ - Frit 411 with a melt rate of $0.86 \mathrm{in} / \mathrm{hr}$. Using equation (1), the baseline waste throughput value is $51 \mathrm{lb} / \mathrm{hr}$. Values exceeding this baseline indicate an increase in total waste throughput potential; while values less than $51 \mathrm{lb} / \mathrm{hr}$ indicate a decreased waste throughput.

The waste throughput potentials for Frit 202 were considered as well, given the frit's classification as a baseline frit by Elder (2002). At 30\% WL, the potential throughput is 38.53 $\mathrm{lb} / \mathrm{hr}$, which is well below the $51 \mathrm{lb} / \mathrm{hr}$ base case. Although the void volume in the cold cap was low, the low melt rate is a concern for this system. As WL increases to $35 \%$, the throughput potential rapidly increases to $53.55 \mathrm{lb} / \mathrm{hr}$ but diminishes upon further WL increases. The erratic behavior of this system may be due to secondary effects such as the acid addition strategy, oxalate, and/or coal.

The Frit 411 system appears to be one of the most attractive systems for Decant \#9. Although melt rate gradually decreases with WL, total waste throughput increases. This result should be taken advantage of if possible.

Total waste throughputs for the Frit 422 system also continue to increase with WL. However, the throughput values are all relatively low with only the $40 \% \mathrm{WL}$ case exceeding the base $51 \mathrm{lb} / \mathrm{hr}$. Assuming all other factors equal, selection of Frit 411 may be advantageous over Frit 422.

The Frit 423 throughput values display the same general trend as observed in the Frit 202 systems. The maximum waste throughput potential is reached at $35 \% \mathrm{WL}$. Although a low void volume characterized the cold cap, the low relative waste throughputs are of concern. 
Table 7-7. Waste Throughput and Melt Rate Observations for Decant \#9 Candidate Frits.

\begin{tabular}{|c|c|c|}
\hline \multicolumn{3}{|l|}{ Frit 202} \\
\hline$\overline{\mathrm{WL}}$ & Throughput (lb/hr) & Comments \\
\hline $30 \%$ & 38.53 & \multirow{3}{*}{$\begin{array}{ll}- & \text { low void volume } \\
\text { - } & \text { large window }\end{array}$} \\
\hline $35 \%$ & 53.55 & \\
\hline $40 \%$ & 42.31 & \\
\hline \multicolumn{3}{|l|}{ Frit 411} \\
\hline WL & Throughput (lb/hr) & Comments \\
\hline $30 \%$ & 51.00 (Baseline) & \multirow{3}{*}{$\begin{array}{ll}- & \text { high void volume } \\
\text { - } & \text { large window }\end{array}$} \\
\hline $35 \%$ & 56.86 & \\
\hline $40 \%$ & 59.69 & \\
\hline \multicolumn{3}{|l|}{ Frit 422} \\
\hline$\overline{\mathrm{WL}}$ & Throughput (lb/hr) & Comments \\
\hline $30 \%$ & 41.93 & \multirow{3}{*}{$\begin{array}{ll}- & \text { low void volume } \\
\text { - } & \text { large window }\end{array}$} \\
\hline $35 \%$ & 49.58 & \\
\hline $40 \%$ & 52.13 & \\
\hline \multicolumn{3}{|l|}{ Frit 423} \\
\hline$\overline{\mathrm{WL}}$ & Throughput (lb/hr) & Comments \\
\hline $30 \%$ & 48.17 & \multirow{3}{*}{$\begin{array}{ll}- & \text { low void volume } \\
- & \text { large window }\end{array}$} \\
\hline $35 \%$ & 58.18 & \\
\hline $40 \%$ & 51.38 & \\
\hline
\end{tabular}

The only candidate frits common to each decant's list are Frit 202 and Frit 423 . Both of these frits have relatively high melt rates and waste throughputs within each decant. Based solely on these two parameters, selection of one of these frits could be beneficial to DWPF given the flexibility it would provide in terms of sludge compositional space. More specifically, selecting either Frit 202 or Frit 423 would allow DWPF to process both Decant \#5 and Decant \#9 and provide operational flexibility to the facility in terms of targeting a specific decant given the uncertainties of the final SB3 composition.

The balance between operational flexibility and attaining optimal waste throughput will be a critical issue in the SB3 frit down-select process. For example, if Decant \#5 is targeted, Frit 202 appears to provide the maximum waste throughput. However, the frit selection process should fold into its assessment the projected operational windows. The latter could be used to select Frit 423 over Frit 202 given the small operational window for the Frit 202 / Decant \#5 system. Frit 423 would provide more operational flexibility to DWPF but may not optimize waste throughput. 


\subsection{Summary}

Recent directives from the U.S. Department of Energy have been focused on accelerated clean-up missions for the various sites around the DOE complex. The SRS has developed a program to meet this new directive. With respect to the DWPF, a "vision case" has been developed which reduces the overall immobilization campaign by several years. This reduction is based on several parameters; two of which are increases in melt rate and waste loading - which ultimately define the total waste throughput potential for a given system. To support this incentive, the SRTC is focusing on increasing waste loading and/or improving melt rates via strategic glass formulation, changing acid addition strategies, and reassessing process control models to challenge their extreme conservatism.

To support strategic glass formulation efforts, SRTC also developed an integrated methodology from which alternative frits for specific sludge batches can be assessed in terms of their operational flexibility potential for DWPF. There are several key criteria or aspects that form the basis of the integrated methodology - one of which is melt rate. Including an assessment of melt rate in the integrated strategy lowers the risk of introducing a feed into DWPF that although on paper is very attractive (in terms of waste loading) results in a very difficult feed to process (in terms of melt rate). In addition, the strategy also focuses on identifying the parameters that define optimal waste throughput, which may be a compromise between waste loading and melt rate.

The objective of this task was to assess the influence of frit composition on the melt rate and melting behavior for two separate SB3 washing scenarios (e.g., decants) utilizing the dry-fed melt rate furnace (MRF). The specific decants assessed were Decant \#5 and Decant \#9. Given melt rate can also be influenced by other factors such as acid addition strategy and/or waste loading, the test program was developed to isolate these effects to the extent possible in order to assess the impact of frit composition. It is assumed that the acid addition strategy used in these tests had minimal impact on the results. It is recognized that the SB3 melt rate assessments are based solely on the dry-fed MRF results which induces some risks, although low, based on recent data linking the dry-fed system to slurry fed melters. The major results from this study are summarized below for each decant.

\section{Decant \#5}

There were discernable differences in melt rate and melt behavior (observations of the cold cap and void volume were made) as a function of frit composition for Decant \#5, which led to the identification of four frits as primary candidates. These frits include: Frit 202, Frit 409, Frit 421, and Frit 423. Table 8-1 summarizes the major findings for these four frit systems. 
Table 8-1. Summary Information for the Primary Decant \#5 Frits.

\begin{tabular}{||l|c|c|c|c||}
\hline & $\begin{array}{c}\text { Frit } \\
409\end{array}$ & $\begin{array}{c}\text { Frit } \\
421\end{array}$ & $\begin{array}{c}\text { Frit } \\
423\end{array}$ & $\begin{array}{c}\text { Frit } \\
202\end{array}$ \\
\hline WL (nom) & $33-50$ & $30-44$ & $31-44$ & $33-39$ \\
\hline WL all EVs & $36-41$ & $34-35$ & $36-37$ & None \\
\hline$\%$ EVs some WL & $100 \%$ & $100 \%$ & $100 \%$ & $70 \%$ \\
\hline WL range of 5\% & $100 \%$ & $87.8 \%$ & $90.2 \%$ & $51.6 \%$ \\
\hline Min. WL range & $6 \%$ & --- & --- & --- \\
\hline Linear MR (30\% WL) & 0.92 & 0.98 & 1.05 & NM \\
\hline Linear MR (35\% WL) & 0.91 & 0.99 & 0.81 & 1.04 \\
\hline Linear MR (40\% WL) & NM & 0.94 & 0.73 & 1.00 \\
\hline Throughput (30\% WL) & 44.69 & 47.60 & 51.00 & --- \\
\hline Throughput (35\% WL) & 51.57 & 56.10 & 45.90 & 58.93 \\
\hline Throughput (40\% WL) & --- & 60.88 & 47.28 & 64.76 \\
\hline \hline
\end{tabular}

Based on the summary information presented in Table 8-1 the following observations were made:

Melt rates for three of the four frits (Frit 423 being the exception) were essentially constant as a function of WL. The independence of melt rate as a function of WL is a characteristic one would like to take advantage of given its direct relationship with total waste throughput potential.

$>$ Total waste throughputs increase as a function of increasing WL for three of the four systems - again, Frit 423 being the exception. Although total throughput for Frit 423 does slightly decrease, it should be noted that the melt rates for this system as a function of WL are comparable to the Frit 320 / SB2 system (see Table 7-4).

$>$ The projected small operational window and the inability to handle compositional variation to a high degree (based on model predictions) may offset the potential advantages of melt rate and waste throughput for the Frit 202 system. The need to balance conflicting goals such as these will weigh heavily on the SB3 frit development team as all the information is assimilated and processed during the final frit selection process leading to a recommendation for SB3.

$>$ Frit 409 shows a high tolerance to compositional variation and independence of melt rate as a function of waste loading, but potential inability of a vendor to fabricate this frit is a concern. Although low relative to the other primary Decant \#5 frits, melt rates for the Frit 409 system are comparable to the Frit 320 / SB2 system as a function of WL.

$>$ Frit 421 is probably the leading Decant \#5 candidate given melt rate is independent of WL over the WL interval studied. This leads to a continual increase in total waste throughput as WL is increased.

\section{Decant \#9}

Unlike the melt rates for Decant \#5, the impact of frit composition on melt rate for Decant \#9 was not as discernable. Given that, the down-select process was not only based on measured melt rates, but also on observations of the cold cap in terms of potential melt behavior and void volume. This information was used to identify four primary frits for Decant \#9. These are: Frit 
202, Frit 411, Frit 422, and Frit 423. Table 8-2 summarizes the major findings for these four frit systems.

Table 8-2. Summary Information for the Primary Decant \#9 Frits.

\begin{tabular}{||l|c|c|c|c||}
\hline \hline & $\begin{array}{c}\text { Frit } \\
422\end{array}$ & $\begin{array}{c}\text { Frit } \\
423\end{array}$ & $\begin{array}{c}\text { Frit } \\
202\end{array}$ & $\begin{array}{c}\text { Frit } \\
411\end{array}$ \\
\hline WL (nominal) & $30-45$ & $28-45$ & $29-44$ & $26-46$ \\
\hline WL all EVs & $33-37$ & $32-37$ & $33-36$ & $30-38$ \\
\hline \% EVs some WL & $100 \%$ & $100 \%$ & $100 \%$ & $100 \%$ \\
\hline WL range of 5\% & $100 \%$ & $100 \%$ & $100 \%$ & $100 \%$ \\
\hline Min. WL range & $6 \%$ & $10 \%$ & $9 \%$ & $9 \%$ \\
\hline Linear MR (30\% WL) & 0.74 & 0.85 & 0.68 & 0.86 \\
\hline Linear MR (35\% WL) & 0.75 & 0.88 & 0.81 & 0.79 \\
\hline Linear MR (40\% WL) & 0.69 & 0.68 & 0.56 & 0.74 \\
\hline Throughput (30\% WL) & 41.93 & 48.17 & 38.53 & 51.00 \\
\hline Throughput (35\% WL) & 49.58 & 58.18 & 53.55 & 56.86 \\
\hline Throughput (40\% WL) & 52.13 & 51.38 & 42.31 & 59.69 \\
\hline \hline
\end{tabular}

Based on the summary information presented in Table 8-2 the following observations were made:

All four Decant \#9 primary frits demonstrate a high degree of tolerance for the anticipated compositional variation.

$>$ The melt rates for the Decant \#9 systems are lower than the Decant \#5 systems. Assuming the acid addition strategy had no impact, this provides some incentive to target a less washed sludge.

$>$ Although the melt rate decreases with increased WL for the Frit 411 system, the total waste throughput for this high alkali-containing frit system increases up through $40 \%$ WL.

$>$ Total waste throughput for the Frit 422 system also increases with increased WL - although the projected values are slightly less than those for Frit 411.

$>$ Melt rates for both the Frit 202 and Frit 423 systems reach a maximum at 35\% WL. For the Frit 202 system, melt rate and total waste throughput are extremely low at $30 \%$ and $40 \%$ WLs.

These results represent an important part of the overall strategy for frit development and optimization for this sludge batch and contribute, along with the supporting paper studies and glass variability studies, to the information that will be evaluated to select a frit for this sludge batch. The viability of this overall strategy as a reliable approach for frit development and optimization for future sludge batches is also demonstrated. 


\subsection{Recommendations}

Based on the results of the SB3 melt rate assessments, the following recommendations are made:

(1) A slurry-fed melter run should be performed in the SMRF. Various objectives should be established prior to running the test(s).

It is recommended that the objectives for initial tests compile and demonstrate the results of the various research programs (e.g., frit development, REDOX, and acid addition strategy) supporting the development of the SB3 integrated flowsheet. More specifically, the objective of the test should be to establish that a "workable" flowsheet is possible for SB3. The term "workable" implies that no major issues are observed during the SRAT/SME cycles, no significant melter issues are encountered (such as excessive foaming or extremely low melt rates), and that a glass product can be produced. It should be noted that the intent of this initial test would not be a demonstration of an "optimized" flowsheet, but strictly a "workable" flowsheet from which process changes could be made. It should be noted that Frit 202 may be required for these initial tests given the lead time for fabrication and receipt of an alternative frit.

(2) Once the acid addition and/or redox control strategy is finalized, it is recommended that the MRF be used to assess the impact of the "finalized" strategy on melt rate for select frit/sludge systems.

(3) Given the identification of a primary frit candidate and washing scenario, additional MRF tests should be performed to demonstrate reproducibility of the results obtained in this study as well as to measure melt rate and waste throughput as a function of WL in smaller increments.

(4) A cost-benefit analysis should be performed to fully understand the following: 1) the advantages and disadvantages of selecting a targeted washing scenario, and 2) the benefits of fewer canisters having to be stored in a repository and shorter operational time to treat sludge, with higher waste loading and higher waste throughput.

(5) Perform a paper study assessment of the latest Tank 7 sample(s).

This assessment would include a review or comparison of the measured Tank 7 composition as it relates to the projected decants used in the SB3 Frit Development program. Based on that comparison, the primary SB3 candidate frits could be quickly assessed using the integrated methodology. The results of the paper study assessment would provide valuable insight in the applicability of previously developed frits or the need to slightly alter frit compositions to compensate for unanticipated compositional differences between the sludges. Limited melt rate tests may be required based on the compositional comparisons.

(6) SMRF runs should be completed with candidate Frits 409, 411, 421, and 423 with Decants \#5 and/or \#9. Upon completion of these SMRF runs, and once the Tank 7 sample(s) have been analyzed, and a decision on the decant has been made (Decant \#5 or $\# 9)$, a recommendation of a frit for SB3 may be determined. 
Immobilization Technology Section

WSRC-TR-2003-00027

Savannah River Technology Center

Rev. 0

Westinghouse Savannah River Company 


\subsection{References}

Bronikowski, MG, MC Thompson, FR Graham, TL Fellinger, WR Wilmarth, and DT Hobbs, 2002. Technical Task and Quality Assurance Plan for Assessing Downstream Effects of Plutonium/Gadolinium in Sludge Washing and SRAT, WSRC-RP-2002-00178, Westinghouse Savannah River Company, Aiken, SC.

Brown KG, CM Jantzen, and G Ritzhaupt. 2001. Relating Liquidus Temperature to Composition for Defense Waste Processing Facility (DWPF) Process Control, WSRC-TR-2001-00520, Westinghouse Savannah River Company, Aiken, SC.

Elder, HH. 2002. Impact of Processing Americium and Curium in ESP, DWPF, and Saltstone, Savannah River Site, High Level Waste Process Engineering Position Paper, HLW-SDT-200100244, Rev. 1, Westinghouse Savannah River Company, Aiken, SC.

Fellinger, TL. 2002. Sludge Batch 3 - Overall Program View (U), WSRC-RP-2002-00353, Westinghouse Savannah River Company, Aiken, SC.

Fowler, JR. 1980. "Estimate of Maximum Amount of Reducing Agents and Sand in the SRP Waste for DWPF TDS”, Don’t Say It Write Memo, September 9, 1980.

Goslen, AQ. 1984. "Estimated Sodium Oxalate in the Tank Farm", March 22, 1984.

Herman CC. 2002a. Task Technical \& QA Plan: Sludge Batch 3 Simulant Flowsheet Studies, WSRC-RP-2002-00563, Westinghouse Savannah River Company, Aiken, SC.

Herman CC. 2002b. Task Technical \& QA Plan: Oxalate Studies for Sludge Batch 3 - SRAT Processing, WSRC-RP-2002-00320, Westinghouse Savannah River Company, Aiken, SC.

Herman, CC, DK Peeler, and TB Edwards. 2002. Task Technical and QA Plan: Sludge Batch 3 Variability Studies with Simulants, WSRC-RP-2002-00386, Westinghouse Savannah River Company, Aiken, SC.

Herman, CC, TL Fellinger, NE Bibler, and DC Koopman. 2002a. Scoping SRAT Runs with Simulated Sludge Batch 3, SRT-GPD-2002-00044, Westinghouse Savannah River Company, Aiken, SC.

Herman CC, TB Edwards, DC Koopman, DR Best, JC George, and MF Williams. 2002b. Data Summary from Sludge Batch 3 Simulant SRAT Runs to evaluate Impacts of Noble Metal Mass and Coal Size, Mass and Treatment, SRT-GPD-2002-00121, Westinghouse Savannah River Company, Aiken, SC.

Herman CC, DR Best, DC Koopman, and MF Williams. 2003. Data Summary from SRAT Runs SB3-19 to SB3-24 to Evaluate Sodium Oxalate Addition Levels and SME Processing, SRT-GPD2002-00200, Westinghouse Savannah River Company, Aiken, SC.

HLW. 2002. PMP Supplement to HLW System Plan Rev. 13, HLW-2002-00161, Westinghouse Savannah River Company, Aiken, SC. 
Jantzen, CM, RF Swingle, and FG Smith. 2002. Impact of Tank 19F Zeolite Mound on DWPF Vitrification of Sludge Batch 3, WSRC-TR-2002-00288, Rev. 0, Westinghouse Savannah River Company, Aiken, SC.

Jantzen, CM. 2002. REDOX Studies and Modeling for DWPF Sludge Batch 3, WSRC-RP-200200341, Westinghouse Savannah River Company, Aiken, SC.

Jilani, I. 2002. Evaluation of Impact of HLW of Using Gadolinium as a Neutron Poison for Plutonium, Technical Task Request, NMMD-HTS-2002-010, Westinghouse Savannah River Company, Aiken, South Carolina.

Koopman, DC, CC Herman, and NE Bibler. 2003. Sludge Batch 3 Preliminary Acid Requirement Studies of Tank 8 Simulant, WSRC-TR-2003-00041, Westinghouse Savannah River Company, Aiken, SC.

Lambert, DP, TH Lorier, DK Peeler, and ME Stone. 2001. Melt Rate Improvement for DWPF MB3: Summary and Recommendations, WSRC-TR-2001-00148, Westinghouse Savannah River Company, Aiken, SC.

Lorier, TH and PL McGrier. 2002. Melt Rate Improvement for the DWPF: Higher Waste Loading Testing, WSRC-TR-2002-00344, Westinghouse Savannah River Company, Aiken, SC.

Lorier TH, TM Jones, and DC Witt. 2002. Melt Rate Testing for the DWPF: Summary of FY02 Testing, WSRC-TR-2002-00545, Westinghouse Savannah River Company, Aiken, SC.

Lorier TH. 2002a. SB3 SRAT Product (Decant \#5) Preparation for Melt Rate Test: 15-Liter Batch, SRT-GPD-2002-00124, Westinghouse Savannah River Company, Aiken, SC.

Lorier TH. 2002b. SB3 SRAT Product (Decant \#9) Preparation for Melt Rate Test: 15-Liter Batch, SRT-GPD-2002-00157, Westinghouse Savannah River Company, Aiken, SC.

Miller, DH. 2002. Summary of Results from Minimelter Run with Macrobatch 3 Baseline Feed Using Frit 320, WSRC-TR-2002-00188, Westinghouse Savannah River Company, Aiken, SC.

Patel, PM. 2002. Evaluation of Impacts of Sludge Containing “Americium/Curium” on $\mathrm{H}_{2}$ Generation and Glass Quality, Technical Assistance Request, HLW/DWPF/TAR-02-0007, Westinghouse Savannah River Company, Aiken, SC.

Peeler DK, TH Lorier, DF Bickford, DC Witt, TB Edwards, KG Brown, IA Reamer, and RJ Workman. 2001. Melt Rate Improvement for DWPF MB3: Frit Development and Model Assessment, WSRC-TR-2001-00131, Westinghouse Savannah River Company, Aiken, SC.

Peeler, DK, NE, Bibler, and TB Edwards. 2002a. An Assessment of the Impacts of Adding $\mathrm{Am} / \mathrm{Cm}$ and $\mathrm{Pu} / \mathrm{Gd}$ Waste Streams to Sludge Batch 3 (SB3) on DWPF $\mathrm{H}_{2}$ Generation Rates and Glass Properties, WSRC-TR-2002-00145, Westinghouse Savannah River Company, Aiken, SC.

Peeler DK and TB Edwards. 2002. Frit Development for Sludge Batch 3, WSRC-TR-200200491, Westinghouse Savannah River Company, Aiken, SC. 
Peeler, DK, TB Edwards, CC Herman, TH Lorier, DR Best, IA Reamer, and RJ Workman. 2002b. Sludge Batch 3 Phase 1 Variability Study, WSRC-TR-2002-00549, Westinghouse Savannah River Company, Aiken, SC.

Peeler DK and TB Edwards. 2002. Frit Development for Sludge Batch 3, WSRC-TR-200200491, Revision 0, Westinghouse Savannah River Company, Aiken, SC.

Rios-Armstrong, MA. 2002a. Technical Task Request, Sludge Batch 3 Carbon Content Analysis, HLW/DWPF/TTR-02-0017, Westinghouse Savannah River Company, Aiken, SC.

Rios-Armstrong, MA., 2002b. Technical Task Request, Sludge Batch 3 Variability Studies with Simulants, HLW/DWPF/TTR-02-0027, Westinghouse Savannah River Company, Aiken, SC.

Savannah River Technology Center (SRTC). 2002a. "Batching Procedure," SRTC Procedure Manual, L29, ITS-0001, Westinghouse Savannah River Company, Aiken, SC.

Savannah River Technology Center (SRTC). 2002b. "Melting Procedure," SRTC Procedure Manual, L29, ITS-0003, Westinghouse Savannah River Company, Aiken, SC.

Stone, ME and JE Josephs. 2001. Melt Rate Improvements for DWPF MB3: Melt Rate Furnace Testing, WSRC-TR-2001-00146, Rev. 0, Westinghouse Savannah River Company, Aiken, SC.

Westinghouse Savannah River Company (WSRC). 2001. Savannah River Site High Level Waste System Plan (HLW), HLW-2001-00040, Revision 13, Aiken, SC. 
Immobilization Technology Section

WSRC-TR-2003-00027

Savannah River Technology Center

Rev. 0

Westinghouse Savannah River Company

\section{Appendix A}

Candidate SB3 Frit Compositions as Developed by Peeler and Edwards (2002). 
Immobilization Technology Section

WSRC-TR-2003-00027

Savannah River Technology Center

Rev. 0

Westinghouse Savannah River Company

Table A-1. Nominal Compositions of Candidate Frits (in wt\% on an oxide basis).

\begin{tabular}{||l|c|c|c|c|c|c|c|c|c|c|c|c|c||}
\hline & $\begin{array}{c}\text { Frit } \\
\mathbf{2 0 2}\end{array}$ & $\begin{array}{c}\text { Frit } \\
\mathbf{3 2 0}\end{array}$ & $\begin{array}{c}\text { Frit } \\
\mathbf{4 0 0}\end{array}$ & $\begin{array}{c}\text { Frit } \\
\mathbf{4 0 1}\end{array}$ & $\begin{array}{c}\text { Frit } \\
\mathbf{4 0 2}\end{array}$ & $\begin{array}{c}\text { Frit } \\
\mathbf{4 0 3}\end{array}$ & $\begin{array}{c}\text { Frit } \\
\mathbf{4 0 4}\end{array}$ & $\begin{array}{c}\text { Frit } \\
\mathbf{4 0 5}\end{array}$ & $\begin{array}{c}\text { Frit } \\
\mathbf{4 0 6}\end{array}$ & $\begin{array}{c}\text { Frit } \\
\mathbf{4 0 7}\end{array}$ & $\begin{array}{c}\text { Frit } \\
\mathbf{4 0 8}\end{array}$ & $\begin{array}{c}\text { Frit } \\
\mathbf{4 0 9}\end{array}$ & $\begin{array}{c}\text { Frit } \\
\mathbf{4 1 0}\end{array}$ \\
\hline $\mathrm{Al}_{2} \mathrm{O}_{3}$ & - & - & - & - & - & - & - & - & - & - & - & - & - \\
\hline $\mathrm{B}_{2} \mathrm{O}_{3}$ & 8 & 8 & 20 & 30 & 12 & 15 & 12 & 20 & 15 & 8 & 8 & 8 & 8 \\
\hline $\mathrm{Li}_{2} \mathrm{O}$ & 7 & 8 & - & - & - & 3 & 3 & 5 & 5 & - & 2 & 4 & 5 \\
\hline $\mathrm{Na}_{2} \mathrm{O}$ & 6 & 12 & - & - & - & - & - & - & - & 6 & 6 & 6 & 5 \\
\hline $\mathrm{SiO}_{2}$ & 77 & 72 & 80 & 70 & 88 & 82 & 85 & 75 & 80 & 86 & 84 & 82 & 82 \\
\hline $\mathrm{MgO}$ & 2 & - & - & - & - & - & - & - & - & - & - & - & - \\
\hline & 100 & 100 & 100 & 100 & 100 & 100 & 100 & 100 & 100 & 100 & 100 & 100 & 100 \\
\hline
\end{tabular}

\begin{tabular}{||c|c|c|c|c|c|c|c|c|c|c|c|c|c||}
\hline & $\begin{array}{c}\text { Frit } \\
\mathbf{4 1 1}\end{array}$ & $\begin{array}{c}\text { Frit } \\
\mathbf{4 1 2}\end{array}$ & $\begin{array}{c}\text { Frit } \\
\mathbf{4 1 3}\end{array}$ & $\begin{array}{c}\text { Frit } \\
\mathbf{4 1 4}\end{array}$ & $\begin{array}{c}\text { Frit } \\
\mathbf{4 1 5}\end{array}$ & $\begin{array}{c}\text { Frit } \\
\mathbf{4 1 6}\end{array}$ & $\begin{array}{c}\text { Frit } \\
\mathbf{4 1 7}\end{array}$ & $\begin{array}{c}\text { Frit } \\
\mathbf{4 1 8}\end{array}$ & $\begin{array}{c}\text { Frit } \\
\mathbf{4 1 9}\end{array}$ & $\begin{array}{c}\text { Frit } \\
\mathbf{4 2 0}\end{array}$ & $\begin{array}{c}\text { Frit } \\
\mathbf{4 2 1}\end{array}$ & $\begin{array}{c}\text { Frit } \\
\mathbf{4 2 2}\end{array}$ & $\begin{array}{c}\text { Frit } \\
\mathbf{4 2 3}\end{array}$ \\
\hline $\mathrm{Al}_{2} \mathrm{O}_{3}$ & 1 & - & - & - & - & 1 & - & - & - & 1 & 1 & - & - \\
\hline $\mathrm{B}_{2} \mathrm{O}_{3}$ & 8 & 8 & 9 & 8 & 10 & 8 & 8 & 8 & 8 & 8 & 10 & 8 & 10 \\
\hline $\mathrm{Li}_{2} \mathrm{O}$ & 5 & 5 & 5 & 6 & 5 & 8 & 8 & 8 & 8 & 5 & 5 & 8 & 8 \\
\hline $\mathrm{Na}_{2} \mathrm{O}$ & 12 & 12 & 15 & 14 & 15 & 11 & 11 & 8 & 15 & 7 & 7 & 3 & 3 \\
\hline $\mathrm{SiO}_{2}$ & 74 & 75 & 71 & 72 & 70 & 72 & 73 & 76 & 69 & 79 & 77 & 81 & 79 \\
\hline $\mathrm{MgO}$ & - & - & - & - & - & - & - & - & - & - & - & - & - \\
\hline & 100 & 100 & 100 & 100 & 100 & 100 & 100 & 100 & 100 & 100 & 100 & 100 & 100 \\
\hline
\end{tabular}

